\title{
Potential environmental impact of tidal energy extraction in the Pentland Firth at large spatial scales: results of a biogeochemical model
}

\author{
Johan van der Molen ${ }^{1}$, Piet Ruardij ${ }^{2}$, and Naomi Greenwood ${ }^{1,3}$ \\ ${ }^{1}$ The Centre for Environment, Fisheries and Aquaculture Science (Cefas), Lowestoft, UK \\ ${ }^{2}$ Royal Netherlands Institute for Sea Research (NIOZ), Den Burg, Texel, the Netherlands \\ ${ }^{3}$ School of Environmental Sciences, University of East Anglia, Norwich, UK
}

Correspondence to: Johan van der Molen (johan.vandermolen@cefas.co.uk)

Received: 20 October 2015 - Published in Biogeosciences Discuss.: 21 December 2015

Revised: 30 March 2016 - Accepted: 5 April 2016 - Published: 2 May 2016

\begin{abstract}
A model study was carried out of the potential large-scale $(>100 \mathrm{~km})$ effects of marine renewable tidal energy generation in the Pentland Firth, using the 3D hydrodynamics-biogeochemistry model GETM-ERSEMBFM. A realistic $800 \mathrm{MW}$ scenario and a high-impact scenario with massive expansion of tidal energy extraction to $8 \mathrm{GW}$ scenario were considered. The realistic $800 \mathrm{MW}$ scenario suggested minor effects on the tides, and undetectable effects on the biogeochemistry. The massiveexpansion $8 \mathrm{GW}$ scenario suggested effects would be observed over hundreds of kilometres away with changes of up to $10 \%$ in tidal and ecosystem variables, in particular in a broad area in the vicinity of the Wash. There, waters became less turbid, and primary production increased with associated increases in faunal ecosystem variables. Moreover, a one-off increase in carbon storage in the sea bed was detected. Although these first results suggest positive environmental effects, further investigation is recommended of (i) the residual circulation in the vicinity of the Pentland Firth and effects on larval dispersal using a higher-resolution model and (ii) ecosystem effects with (future) state-of-the-art models if energy extraction substantially beyond $1 \mathrm{GW}$ is planned.
\end{abstract}

\section{Introduction}

\subsection{Background}

Techniques to generate marine renewable energy are maturing, with wind turbines currently being installed in their hundreds to thousands, and first commercial models of tidal energy generators are becoming available, with wave-energy generators not far behind and macro-algae farming at the field-testing research stage. Energy in the atmospheric and marine environment is a resource that is not replenished immediately and at a local scale by solar or orbital sources, and is subject to physical conservation laws. Hence, extracting energy for human use leaves less energy remaining in the system, at least for some distance downstream of the extraction area. As a result, if applied in large farms with hundreds of devices, marine renewable energy extraction has the potential to noticeably alter the local and regional hydrography, and through that influence the marine ecosystem. Potential effects on the physical marine environment include changes in tidal currents, residual circulation, wave climate, bed-shear stress and associated transport of materials, turbulence, turbidity, water temperature, salinity and stratification, and noise levels. Knock-on effects on the biological marine environment could include changes in nutrient and plankton transport (including larval stages), changes in primary production, changes in food availability and feeding and migration behaviour, and resulting changes in species composition and distribution. All of these potential effects, including many others, have been identified in a series of review studies 
(Gill, 2005; Cada et al., 2007; Boehlert and Gill, 2010; Frid et al., 2012; Kadiri et al., 2012; Hooper and Austen, 2013). Whereas effects on the local hydrodynamics are often investigated as part of the design procedure, potential larger-scale effects on the hydrodynamics and in particular the ecosystem are largely unknown, although the first studies are starting to emerge (see Neil et al., 2009, for tidal turbine effects on sediment dynamics in the Bristol Channel; Wolf et al., 2009, for effects of multiple tidal barrages in the Irish sea; Defne et al., 2011, for tidal energy extraction on estuarine hydrodynamics in Georgia, USA; Shapiro, 2011 for a hypothetical tidal farm in the Celtic Sea; Ahmadian and Falconer, 2012, for effects of tidal turbines on the hydrodynamics in the Bristol Channel; Aldridge et al., 2012, for a hypothetical macro-algae farm in the north-western North Sea; and van der Molen et al., 2014, for a hypothetical wind farm in the North Sea). These studies found a varying degree of potential impacts, depending on the location, the extraction technique and (subset of) processes under investigation and the models and assumptions used. These first results, combined with increasing (inter)national legislation to regulate the anthropogenic use of the marine environment (eg., the Marine Strategy Framework Directive (European Commission, 2008) to promote healthy and productive seas), indicate that more should be done to investigate the effects of marine renewable energy extraction on the environment, including combined effects of large-scale extractions and interactions with other economic activities such as fishing, and climate change to ensure that marine renewable energy extraction can be carried out in a sustainable way. As the scales of extraction increase, and various farms/extraction schemes start to interact with one another, more knowledge will become increasingly necessary.

Recently, the Crown Estate has licensed areas in the Pentland Firth and around the Orkney Islands for tidal and waveenergy generation (Crown Estate, 2013). Shields et al. (2009) outlined gaps in the knowledge on ecological impacts of tidal energy extraction in the Pentland Firth. Here, we assume that the licensed tidal power extraction in the Pentland Firth will be realised, and use a coupled hydrodynamicsbiogeochemistry model to investigate the potential largescale (hundreds to thousands of kilometres) effects of on tides, currents, biogeochemistry, and the planktonic and benthic ecosystem. In order to put this into perspective, provide a crude estimate for extrapolation, and give an indication of a far-future scenario and/or potential cumulative effects with (as yet hypothetical) multiple other extraction schemes "upstream" of the Pentland Firth, we also investigated an enhanced and, at the current state of technology, purely academic massive-expansion scenario in which 10 times the licensed amount of energy was extracted. More detailed, local effects, including array optimisation for combinations of criteria including power yield, cost, and environmental effects, were investigated as part of the same project by Funke et al. (2014) and Martin-Short et al. (2015).

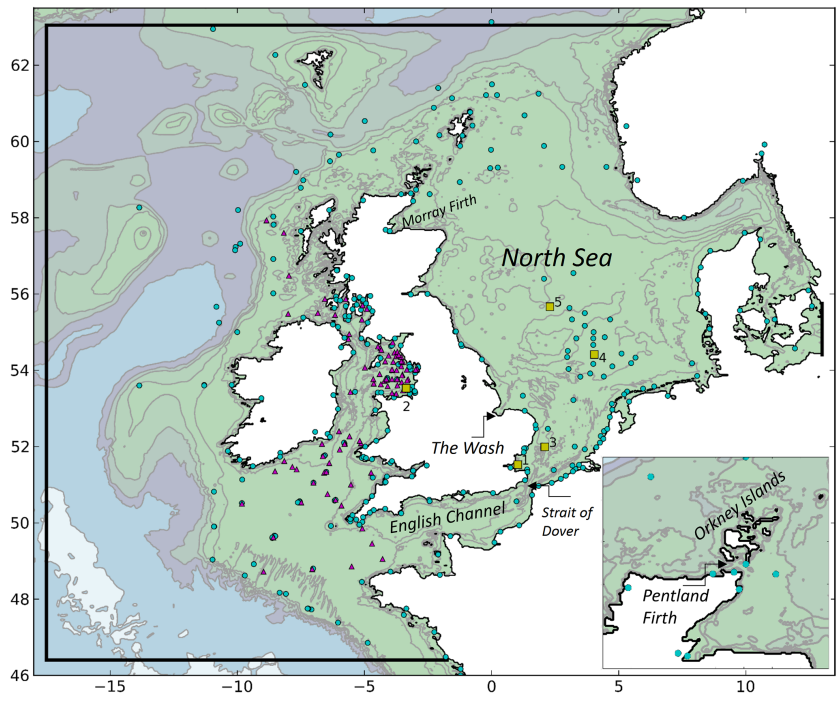

Figure 1. Model area (thick line) with tide gauge (green circles), current meter (purple triangles) stations, and SmartBuoy stations (yellow squares; 1: Warp Anchorage; 2: Liverpool Bay; 3: West Gabbard; 4: Oyster Grounds; 5: North Dogger ). Depth contours: $25,40,80,150,300,600,1200,2400$, and 4800 m. Inset: Pentland Firth area.

\subsection{Study area}

The shelf to the west and north of the UK (Fig. 1) is typically 1 to several hundreds of kilometres wide, and has a depth of 100-200 m. The Celtic and Irish seas separate Ireland from the mainland of the UK, and the English Channel separates the UK from the continent in the south. The North Sea to the east of the UK has typical depths of over $100 \mathrm{~m}$ in the north, and less than $50 \mathrm{~m}$ in the south. The north-west European shelf and, in particular, the North Sea support a high biological production but are at the same time used heavily for a range of economic activities, including shipping, fishing, oil and gas extraction, pipe lines, and aggregate extraction, while also containing a large number of marine protected areas of various types (see e.g. Paramor et al., 2009; OSPAR, 2010).

The Pentland Firth is a narrow strait situated between mainland Scotland and the Orkney Islands. It has a maximum water depth of $80 \mathrm{~m}$ in the main channel, and tidal current speeds in excess of $3 \mathrm{~ms}^{-1}$ (see Easton et al., 2012, for details on the tides in Pentland Firth). It serves as a conduit for some of the tidal energy propagating as Kelvin waves in a clockwise direction on the north-west European continental shelf along the Atlantic coasts of the UK; around the north of Scotland; into the North Sea; down the east coast of the UK; and across to the coasts of the Netherlands, Germany, Denmark, and Norway (see e.g. Holt et al., 2001). Also, some of the residual flows into the North Sea enter through the Pentland Firth. Within the North Sea, the tides interact with the topography, wave climate, and river runoff to create a range of stratification and mixing conditions (Pingree et al., 1978; 
van Leeuwen et al., 2015), as well as sea bed disturbance and transport mechanisms (van der Molen, 2002; Aldridge et al., 2015). The North Sea supports a high level of primary productivity, which has been augmented by varying and, since 1985, gradually reducing levels of anthropogenic riverine nutrient loads, and which depends on local suspended particulate matter (SPM) concentrations that affect the availability of light (e.g. Lenhart et al., 2010).

For five sites (Fig. 1), time-series observations of biogeochemical variables from SmartBuoys (Greenwood et al., 2010) were used for model confirmation (Sect. 3.2). Note that we have followed the definitions of verification, validation and confirmation proposed by Oreskes et al. (1994). Site 1, Warp Anchorage, is situated in well-mixed conditions at $15 \mathrm{~m}$ water depth in a channel in the Thames Estuary. Site 2, Liverpool Bay, is situated in intermittently stratified, river-influenced conditions (e.g. Verspecht et al., 2009) at $23 \mathrm{~m}$ water depth in the eastern Irish Sea, and forms part of the Liverpool Bay Coastal Observatory (https://www.bodc. ac.uk/data/information_and_inventories/edmed/report/224/). Site 3, West Gabbard, is situated in well-mixed conditions in $32 \mathrm{~m}$ water depth in the southern bight of the North Sea. Site 4, Oyster Grounds, was situated in mostly seasonally stratified waters in $45 \mathrm{~m}$ water depth. Site 5, North Dogger, was situated in seasonally stratified waters in $80 \mathrm{~m}$ water depth. Sites 4 and 5 were studied extensively as part of the Marine Ecosystem Connections programme (see Painting and Foster, 2013, and references therein).

\section{Methods}

\subsection{SmartBuoys}

SmartBuoys are instrumented moorings deployed to make high-frequency measurements of physical, chemical, and biological variables (Mills et al., 2005), which are published online (https://www.cefas.co.uk/publications-data/ smartbuoys/). SmartBuoys have been deployed in UK and Dutch waters as components of monitoring programmes designed to meet the needs of international legislation such as the Marine Strategy Framework Directive and within specific research projects. SmartBuoys were configured to determine turbidity, chlorophyll fluorescence, salinity, temperature, and dissolved oxygen and data were processed according to Greenwood et al. (2010). Concentrations of suspended particulate matter and chlorophyll were derived from measurements of turbidity and chlorophyll fluorescence respectively (Greenwood et al. 2010).

Discrete samples were collected on all SmartBuoys using an automated Aquamonitor and subsequently analysed for TOxN (total oxidisable nitrogen) and silicate according to Gowen et al. (2008). In addition, on Warp, West Gabbard, Liverpool Bay, and North Dogger, TOxN was determined using an automated in situ NAS-2E or NAS-3X nutrient anal- yser. Daily mean values were calculated from all data which passed the quality assurance process. All SmartBuoys in this study were operational for the whole period apart from North Dogger, which was deployed between February 2007 and September 2008.

\subsection{North-west European shelf setup for GETM-ERSEM}

The 3-D hydrodynamic model GETM (General Estuarine Transport Model, www.getm.eu; Burchard and Bolding, 2002) solves the shallow-water, heat balance, and density equations. It uses GOTM to solve the vertical dimension. For the current work, GETM was run on a spherical grid covering the area $46.4-63^{\circ} \mathrm{N}, 17.25^{\circ} \mathrm{W}-13^{\circ} \mathrm{E}$ with a resolution of $0.02^{\circ}$ longitude and $0.05^{\circ}$ latitude (approximately $5 \mathrm{~km}$ ), and 25 non-equidistant layers in the vertical. The model bathymetry was based on the NOOS bathymetry (www.noos. cc/index.php?id=173). At this resolution, the Pentland Firth is resolved by several model grid cells, which cannot reproduce local detail, but should be sufficient to study the potential far-field effects of tidal energy extraction. The model was forced with tidal constituents derived from TOPEXPOSEIDON satellite altimetry (Le Provost et al., 1998), atmospheric forcing from the ECMWF ERA-40 and Operational Reanalysis (ECMWF, 2006a, b), interpolated river runoff from a range of observational data sets (the National River Flow Archive (www.ceh.ac.uk/data/nrfa/index.html) for UK rivers; the Agence de l'eau Loire-Bretagne, Agence de l'eau Seine-Normandie, and IFREMER for French rivers; the DONAR database for Netherlands rivers; ARGE Elbe, the Niedersächsisches Landesamt für Ökologie, and the Bundesanstalt für Gewässerkunde for German rivers; and the Institute for Marine Research, Bergen, for Norwegian rivers; see also Lenhart et al., 2010) and depth-resolved temperature and salinity boundary conditions from ECMWF-ORAS4 (Balmaseda et al., 2013; Mogensen et al., 2012). Boundary conditions for nutrients are taken from the World Ocean Atlas monthly climatology (Garcia et al., 2010).

The ERSEM-BFM (European Regional Seas Ecosystem Model - Biogeochemical Flux Model) version used here (19 February 2015) is a development of the model ERSEM III (see Baretta et al., 1995; Ruardij and van Raaphorst, 1995; Ruardij et al., 1997, 2005; Vichi et al., 2003, 2004, 2007; van der Molen et al., 2013, 2014; www.nioz.nl/northsea_model) and describes the dynamics of the biogeochemical fluxes within the pelagic and benthic environment. The ERSEMBFM model simulates the cycles of carbon, nitrogen, phosphorus, silicate, and oxygen and allows for variable internal nutrient ratios inside organisms, based on external availability and physiological status. The model applies a functional group approach and contains five pelagic phytoplankton groups, four main zooplankton groups, and five benthic faunal groups, the last of which comprising four macrofauna and one meiofauna groups. Pelagic and benthic aerobic and 
anaerobic bacteria are also included. The pelagic module includes a number of processes in addition to those included in the oceanic version presented by Vichi et al. (2007) to make it suitable for temperate shelf seas: (i) a parameterisation for diatoms allowing growth in spring; (ii) enhanced transparent exopolymer particle (TEP) excretion by diatoms under nutrient stress; (iii) the associated formation of macro-aggregates consisting of TEP and diatoms, leading to enhanced sinking rates and a sufficient food supply to the benthic system especially in the deeper offshore areas (Engel, 2000); (iv) a Phaeocystis functional group for improved simulation of primary production in coastal areas (Peperzak et al., 1998); (v) a pelagic filter-feeder larvae stage; and (vi) benthic diatoms, including resuspension, transport, and pelagic growth. The SPM module, containing contributions by waves and currents, and included for improved simulation of the underwater light climate, has been developed further compared to the version used by van der Molen et al. (2014). It now includes full 3-D transport, according to formulations similar to the method of van der Molen et al. (2009), but uses only one SPM fraction subject to a concentration-dependent settling velocity to parameterise the effects of multiple grain sizes for computational efficiency (van der Molen et al., 2016). An experimental method to include resuspension of particulate organic matter as a proportion of the SPM resuspension is also included.

\subsection{Model implementation of tidal turbines}

For each grid cell in the model that contained tidal turbines, an additional frictional sink term $S_{\mathrm{f}}$ was applied to the $u$ and $v$-momentum equations throughout the water column, using the mechanisms introduced in GETM by Rennau et al. (2012):

$S_{\mathrm{f}, \mathrm{u}}=C_{\mathrm{d}, \mathrm{t}} u \sqrt{\left(u^{2}+v^{2}\right)}, S_{\mathrm{f}, v}=C_{\mathrm{d}, \mathrm{t}} v \sqrt{\left(u^{2}+v^{2}\right)}$,

where $u$ and $v$ are the depth-averaged horizontal velocity components in the longitudinal and latitudinal directions, respectively. The coefficient for the additional friction induced by the tidal turbines $C_{\mathrm{d}, \mathrm{t}}$ was calculated as (S. Kramer, personal communication, 2014)

$C_{\mathrm{d}, \mathrm{t}}=\frac{1}{2} N C_{\mathrm{thr}} \frac{\frac{\pi}{4} D_{\mathrm{rotor}}^{2}}{d x d y H}$,

where $d x$ and $d y$ the local grid spacing in the longitudinal and latitudinal direction, respectively, in metres, $H$ the local instantaneous water depth, $N$ the number of rotors (note that, depending on the make and type, a tidal energy generation device can consist of multiple rotors) in the grid cell, $C_{\mathrm{thr}}$ the non-dimensional thrust coefficient of each rotor, and $D_{\text {rotor }}$ the rotor diameter. For this work, we have assumed Triton 3 tidal stream generators (three rotors of $1 \mathrm{MW}$ each per device, $D_{\text {rotor }}=20 \mathrm{~m}$ ) as well as a typical value $C_{\mathrm{thr}}=0.6$ (note that, in reality, thrust coefficients tend to vary depending on operating conditions).

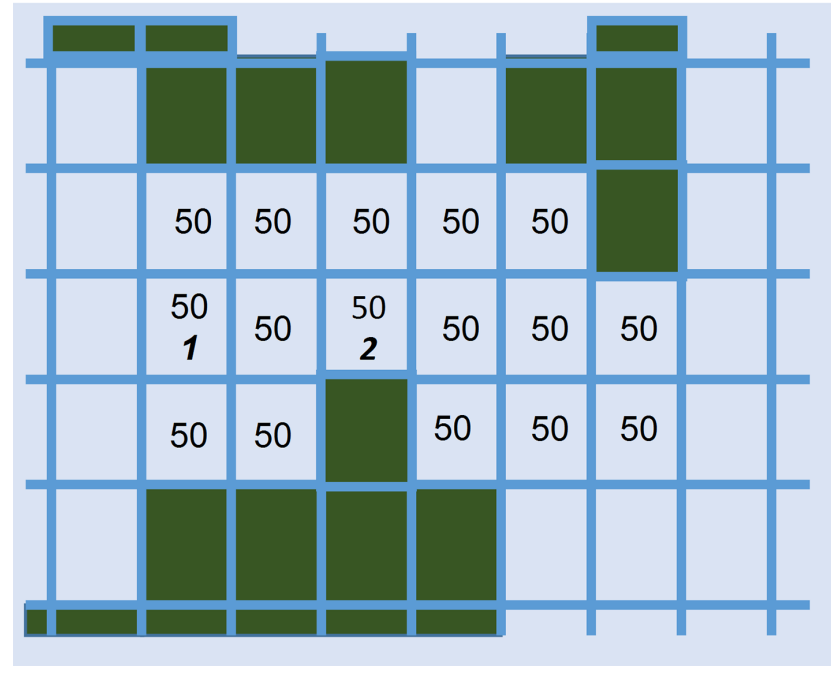

Figure 2. Model grid in the Pentland Firth, with uniform distribution of $800 \mathrm{MW}$ tidal power extraction (numbers in MW). Bold, italic numbers indicate the grid cells coinciding with the ADCP locations. Green coloured cells are land.

\subsection{Model experiments}

Because of differences in response times, and different requirements for model output, separate sets of model runs were carried out to study the effects on tidal propagation and biogeochemistry, respectively.

\subsubsection{Tidal propagation}

The hydrodynamics model was run from 1 January 1997 to 30 June 2001 from initial conditions consisting of a cold start for tides, and 3-D temperature and salinity fields derived from ECMWF-ORAS4. Subsequently, it was run for 6 months storing hourly fields, which were subjected to tidal harmonic analysis, resolving a residual, 5 diurnal, 11 semidiurnal, and 5 shallow-water constituents for elevations and depth-averaged velocity components in the longitudinal and latitudinal directions.

The $\mathbf{M}_{2}$ tidal constituents were compared with data from tide gauges and current meters from Jones (1983), Gjevik and Straume (1989), Smithson (1992), MARIS (personal communication, 1998), FRV (personal communication, 1998), Young et al. (2000), Jones and Davies (2007), and Easton et al. (2012) (see Fig. 1 for locations). In addition, time series of modelled flow velocities within the Pentland Firth were compared with acoustic Doppler current profiler (ADCP) observations (Gardline Surveys, 2001), supplied originally from the Maritime and Coastguard Agency through the Environmental Research Institute and Heriot Watt University (see also Dillon, 2007); see Fig. 2 for locations.

Subsequently, two model scenarios with tidal energy extraction were run: one scenario using a uniform distribution of the planned energy extraction within the Pentland 
Firth (800 MW as currently proposed; Crown Estate, 2013) (see Fig. 2) and a similar scenario extracting $8 \mathrm{GW}$. A uniform distribution was chosen because the shelf model does not resolve the licensed areas; moreover, an $8 \mathrm{GW}$ extraction would likely occupy a substantial proportion of the Pentland Firth. Harmonic analysis was carried out on these results, and the difference with the reference scenario was mapped for (i) the $\mathrm{M}_{2}$ constituent to assess the main impact on overall tidal propagation, (ii) the $\mathrm{M}_{4}$ constituent to assess the main impact on tidal asymmetry and potential effects on the transport of particulate material with a non-zero settling velocity, and (iii) on the residual velocity to assess the potential effects on the transport of particulate and dissolved material.

\subsubsection{Biogeochemistry}

The coupled hydrodynamics-biogeochemical model was run for three years: 2006-2008 (reference run). These years were chosen because of the availability of validation data, and to assess the potential of longer-term accumulation of the potential effects of tidal energy extraction. Longer runs would have been desirable, but were not possible with the financial and computational resource available. The spin-up period covered 2000-2005, with minor fixes to improve model stability applied in January 2004. The biogeochemistry state at the start of the spin-up period was taken from the end results of a run with an earlier, very similar model version covering 1995-2008. Model confirmation of this reference run consisted of a time-series comparison with SmartBuoy observations at five sites representing different hydrographic conditions, involving nutrient concentrations, SPM concentrations, and chlorophyll concentrations (Greenwood et al., 2010). As nitrite concentrations are usually small, we compared modelled nitrate with observed TOxN. Subsequently, three scenario runs were carried out for 2006-2008: a duplicate reference run, and the $800 \mathrm{MW}$ and $8 \mathrm{GW}$ tidal energy extraction scenarios. For the purpose of this paper, annual averages were calculated for all ecosystem variables for each scenario for each year, and differences with the reference run were calculated. Investigation of changes within seasons could be considered for further work. Comparison of the reference run and the duplicate reference run indicated that results for water depths of more than several hundreds of metres (i.e. off the shelf edge, and to some extent in the Norwegian Channel) did not reproduce because of different realisations of stochastically driven eddy-type processes, and that some of these effects propagated onto the shelf, obscuring the effects of the tidal energy extraction. To remove these, the $800 \mathrm{MW}$ and $8 \mathrm{GW}$ scenarios were filtered by, for each ecosystem variable, applying the following mask to each of the wet points in the model:

$$
M=\left[\frac{\left|D_{\mathrm{S}}\right|}{\left|D_{\mathrm{R}}\right|}>T_{1}\right] \&\left[\left|\nabla \frac{D_{\mathrm{R}}}{|R|}\right|<T_{2}\right]
$$

Here, the mask $M$ gets a value of 0 or $1, D_{\mathrm{S}}$ is the difference of the scenario and the reference run, $D_{\mathrm{R}}$ the difference of the reference runs, $R$ the value of the reference run, $T_{1}=2.0$ and $T_{2}=1.0$ empirical thresholds (the values of which were determined by trial and error), and $\nabla$ a gradient operator taking the magnitude of the local spatial gradient scaled by the horizontal grid-averaged value of the wet points. Essentially, this filter removes cells with a small scenario difference compared with the difference between the reference runs, as well as cells where the spatial variability of the difference of the reference runs is high. We acknowledge that this filtering method is relatively crude, and that it could be improved either by taking (multi-)decadal averages or by using means and standard deviations derived from a sufficiently large number of realisations of the reference run. However, these methods would involve a computational effort far beyond the resources available for this project. We are confident that the cost-efficient method applied here is effective enough to support the results presented in this paper.

As renewable energy generation is, among other things, done to reduce $\mathrm{CO}_{2}$ emissions and carbon cycling is an important element of the marine ecosystem, we also looked at effects on $\mathrm{CO}_{2}$ uptake from the atmosphere and particulate carbon storage in the sea bed.

\section{Results}

\subsection{Tidal model confirmation}

Scatter plots of the difference between model and observations at the tide gauge and current meter locations (Figs. 1, 3) showed reasonable agreement for many stations. A substantial number of stations showed substantial differences; these are located mostly within the Irish Sea. $\mathbf{M}_{2}$ elevation amplitudes typically agreed within $20 \mathrm{~cm}$, but with high scatter for amplitudes over $2 \mathrm{~m} . \mathrm{M}_{2}$ phases typically agreed within $30^{\circ} . \mathrm{M}_{2}$ current meter amplitudes (magnitude of the semi-major axis of the current ellipse; exclusively from the Irish and Celtic seas, Fig. 1) mostly agreed within $15 \mathrm{~cm} \mathrm{~s}^{-1}$, with phases within $30^{\circ} . \mathrm{M}_{4}$ tidal elevation amplitudes were mostly within $5 \mathrm{~cm} \mathrm{~s}^{-1}$ of the observations, with high scatter and a suggestion of under-prediction for amplitudes above $5 \mathrm{~cm} \mathrm{~s}^{-1} . \mathrm{M}_{4}$ phases were mostly within $50^{\circ}$.

Considering the spatial distribution of the differences between model and observations in the area of interest around northern Scotland (Fig. 4), $\mathrm{M}_{2}$ elevation amplitudes were mostly within a few centimetres, and $\mathrm{M}_{2}$ phases were within a few degrees. $\mathrm{M}_{4}$ elevation amplitudes were also within a few centimetres, but $\mathrm{M}_{4}$ phase differences were substantial, and negative in the west and positive in the east. In the southern North Sea (Fig. 5a) differences between modelled and observed $\mathrm{M}_{2}$ tidal elevations were typically within a few centimetres for offshore stations, and, with some exceptions, within $10 \mathrm{~cm}$ for coastal stations. $\mathrm{M}_{2}$ tidal phases 

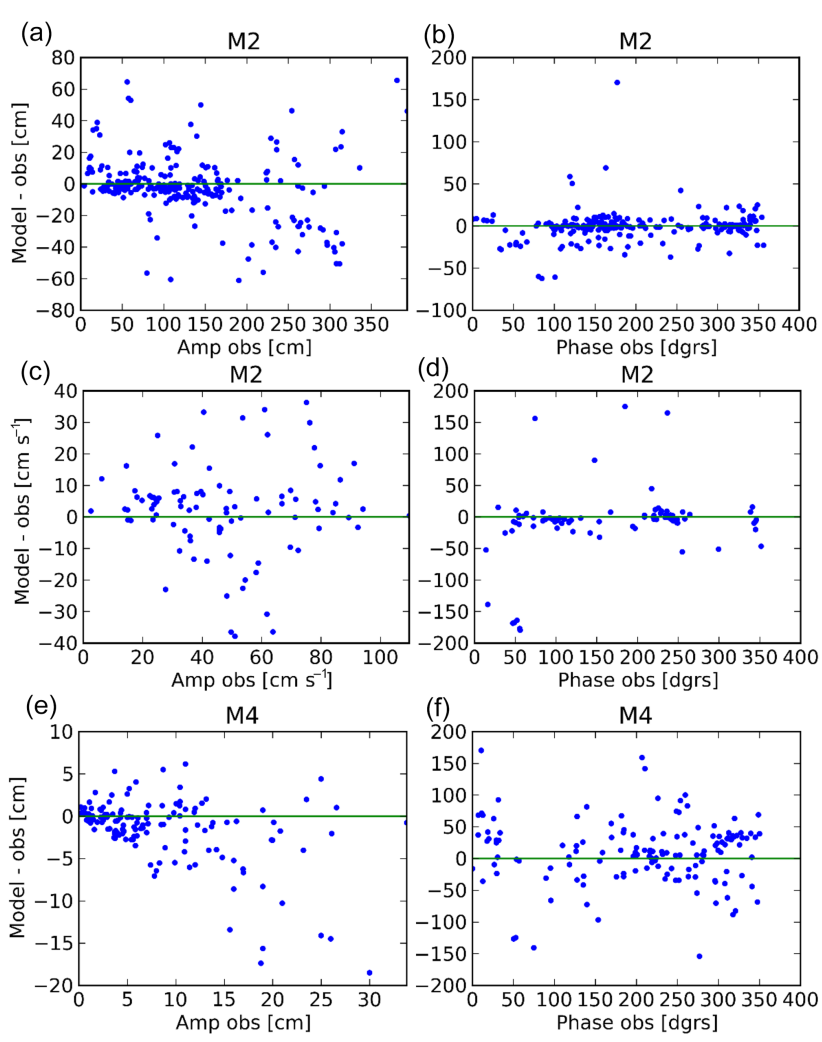

Figure 3. Scatter diagrams of difference of model results and observations for (a, b) $\mathrm{M}_{2}$ tidal elevation amplitudes and phases, (c, d) $\mathrm{M}_{2}$ tidal current speed ellipse semi-major axis and phase, and (d, e) M4 tidal elevation amplitudes and phases.

(Fig. 5b) were typically within $20^{\circ}$. In the Celtic and Irish seas (Fig. 5c) differences between modelled and observed $\mathrm{M}_{2}$ tidal elevations ran up to several tens of centimetres, with overestimations in the Bristol Channel and in the north around the southwestern Scottish islands and underestimations within the Irish Sea. $\mathrm{M}_{2}$ tidal phases (Fig. 5d), with a few exceptions, were typically within $15^{\circ}$.

Modelled current speeds at the ADCP locations (Fig. 6) were more or less in phase with the observations. At ADCP site 1 , the modelled difference between peak flood and ebb currents was substantially smaller than observed, with the model more or less reproducing the ebb currents and underestimating flood currents. At ADCP site 2, the observed asymmetry between flood and ebb currents was much smaller than at site 1 , and the model reproduced the currents very well.

\subsection{Biogeochemical model confirmation}

For SmartBuoy site 1 (Warp Anchorage, Fig. 1), the seasonal cycle in SPM concentrations (Fig. 7a) was reproduced by the model, but peak concentrations were overestimated, probably because the buoy is in a sheltered position behind a sand bank that the model cannot resolve. Chlorophyll concentrations (Fig. 7b) were represented well with good low winter concentrations, a slight early onset of the spring bloom, good representation of peak concentrations, and underestimated autumn bloom values. Nutrient concentrations (Fig. 7c, d) were overestimated substantially by the model, in particular in winter. This is an artifact of the newly introduced organic matter resuspension mechanism, which buries too much material in the coastal zone. This will be addressed in a subsequent model version.

At SmartBuoy site 2 (Liverpool Bay, Fig. 1), SPM concentrations (Fig. 8a) were slightly under-predicted. Chlorophyll concentrations (Fig. 8b) were represented well. In similarity to SmartBuoy site 1, (winter) nutrient concentrations (Fig. 8c, d) were substantially over-predicted.

At SmartBuoy site 3 (West Gabbard, Fig. 1), peak concentrations of SPM (Fig. 9a) were over-predicted, but with good representation of the seasonal cycle. Chlorophyll concentrations (Fig. 9b) were represented well, but with underestimation of the maximum spring bloom in 2 out of the 3 years. Nutrient concentrations (Fig. 9c, d) were represented reasonably well.

SmartBuoy site 4 (Oyster Grounds, Fig. 1) showed good seasonality but an overestimate in peak SPM concentrations (Fig. 10a), good representation of chlorophyll except for an overestimate of spring-bloom values (Fig. 10b), and good representation of nutrient concentrations (Fig. 10c, d).

Winter SPM concentrations (Fig. 11a) at SmartBuoy site 5 (North Dogger, Fig. 1) were overestimated, while chlorophyll concentrations (Fig. 11b) were reasonable. Winter nutrient concentrations (Fig. 11c, d) were approximately half the observed values.

To obtain an impression of how well the model captures temporal and spatial variations in chlorophyll concentrations, the modelled surface chlorophyll concentrations were compared with daily satellite-derived chlorophyll concentrations from the MODIS satellite (http://modis.gsfc.nasa.gov), obtained from the Ifremer ftp server (http://cersat.ifremer.fr/ data/products/catalogue, processed as described by Gohin et al., 2005, and Gohin, 2011) for the growing season of 2008 (Fig. 12). Figure 12a presents the true model mean, and Fig. 12b the satellite mean. The model results were subsampled to account only for clear days to obtain a less biased comparison with the satellite observations (Fig. 12c); see Fig. 12d for the number of clear days according to the satellite. Comparison of Fig. 12a and c suggests that the satellite average may be an overestimate of the true growingseason mean, possibly because of increased chlorophyll production during clear days and/or enhanced vertical mixing 
(a)

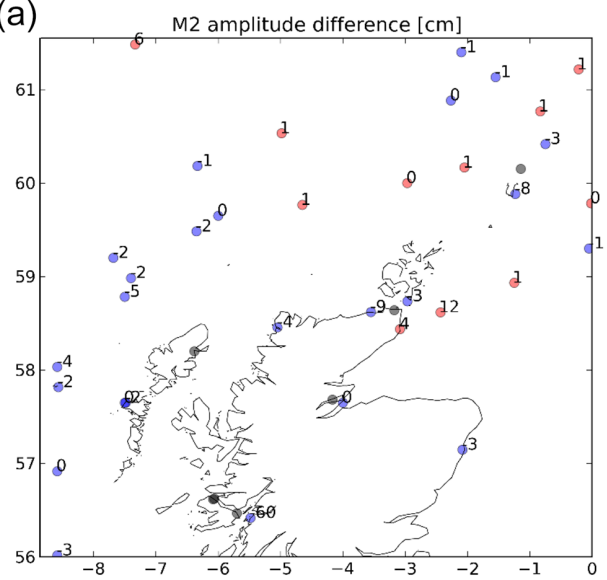

(c)

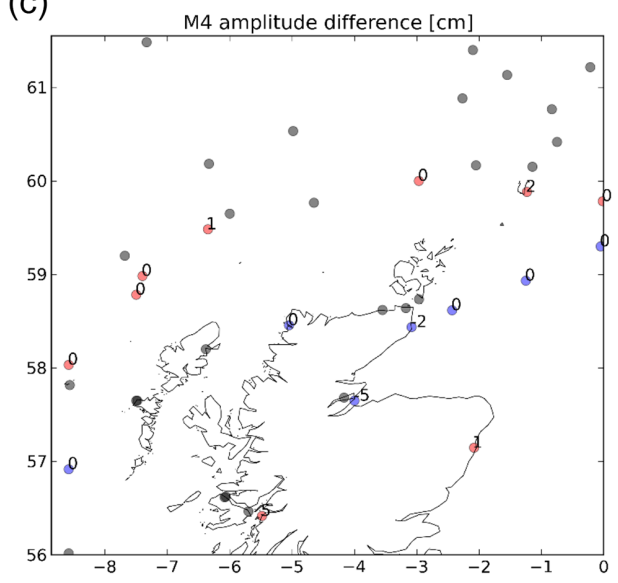

(b)

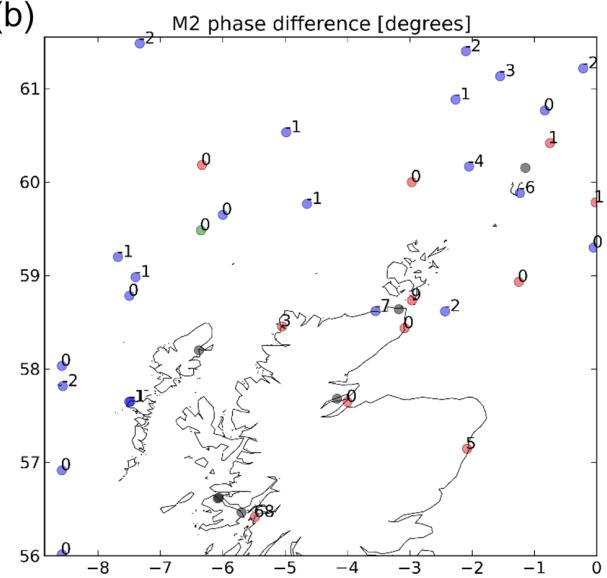

(d)

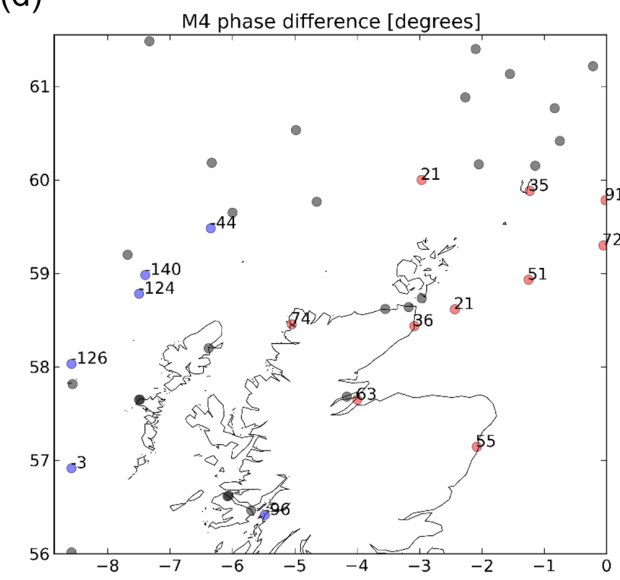

Figure 4. Spatial distribution of difference between model and observations of $\mathrm{M}_{2}$ elevation amplitude (a) and phase (b), and M4 elevation amplitude (c) and phase (d). Blue circles: model smaller than observations; red circles: model larger than observations; grey circles: no data, or dry model grid cell at tide gauge location.

during cloudy (and most likely more windy) days. The bias in model chlorophyll as compared to the satellite (Fig. 12e) suggested an overestimate in coastal chlorophyll concentrations as well as in the area between the Dogger Bank and the continental coast, and slight underestimates in more offshore areas. The correlation between model and satellite was generally positive (Fig. 12f), with areas of poor performance in the Norwegian Trench, the Atlantic Ocean off the shelf edge, and in the area near the Dogger Bank that coincides with the overestimates of the mean. Similar comparisons of SPM concentrations with satellite observations are available in an der Molen et al. (2016).

\subsection{Effects on tides}

For the $800 \mathrm{MW}$ scenario, differences in tidal elevations with the reference scenario were very small (Fig. 13). $\mathrm{M}_{2}$ elevation amplitudes (Fig. 13a) were up to $1 \mathrm{~cm}$ higher to the west of the Pentland Firth, and a few millimetres smaller along the east coast of the UK down to East Anglia. $\mathrm{M}_{4}$ elevation amplitudes (Fig. 13b) were a few millimetres smaller within the Pentland Firth, and up to $1 \mathrm{~mm}$ higher in Moray Firth. For the $8 \mathrm{GW}$ scenario, $\mathrm{M}_{2}$ elevation amplitudes (Fig. 13c) were up to $8 \mathrm{~cm}$ higher to the west of the Pentland Firth, and up to $4 \mathrm{~cm}$ lower along the east coast of the UK. M $\mathrm{M}_{4}$ elevation amplitudes (Fig. 13d) were up to $3 \mathrm{~cm}$ smaller within the Pentland Firth, and up to $1 \mathrm{~cm}$ higher in the Moray Firth.

Considering currents (Fig. 14), for the $800 \mathrm{GW}$ scenario, $\mathrm{M}_{2}$ currents (Fig. 14a) changed by up to $2 \mathrm{~cm} \mathrm{~s}^{-1}$ within the Pentland Firth, and by only a few $\mathrm{mm} \mathrm{s}^{-1}$ elsewhere. Changes in residual velocities (Fig. 14b) were up to $3 \mathrm{~cm} \mathrm{~s}^{-1}$ in the Pentland Firth and very small elsewhere. For the $8 \mathrm{GW}$ scenario, $\mathrm{M}_{2}$ currents (Fig. 14c) were similar within the Pentland Firth, and up to $10 \mathrm{~cm} \mathrm{~s}^{-1}$ different on either side of the Pentland Firth. Changes in residual velocities (Fig. 14d) were up to $10 \mathrm{~cm} \mathrm{~s}^{-1}$ in the immediate vicinity of the Pentland Firth, and up to $5 \mathrm{~cm} \mathrm{~s}^{-1}$ at considerable distance away from the Pentland Firth. 
(a)

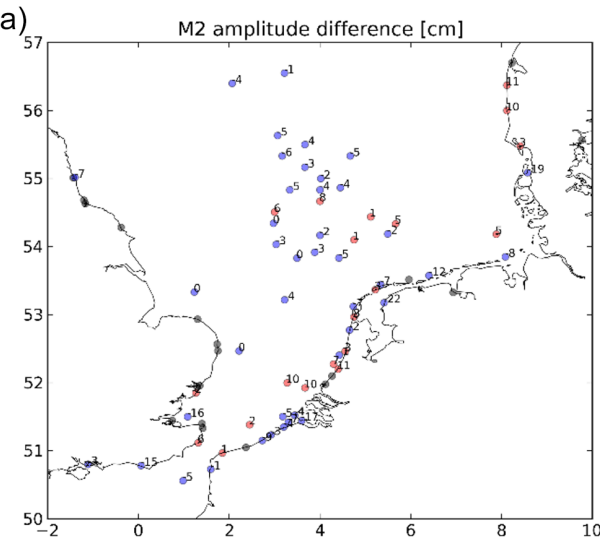

(c)

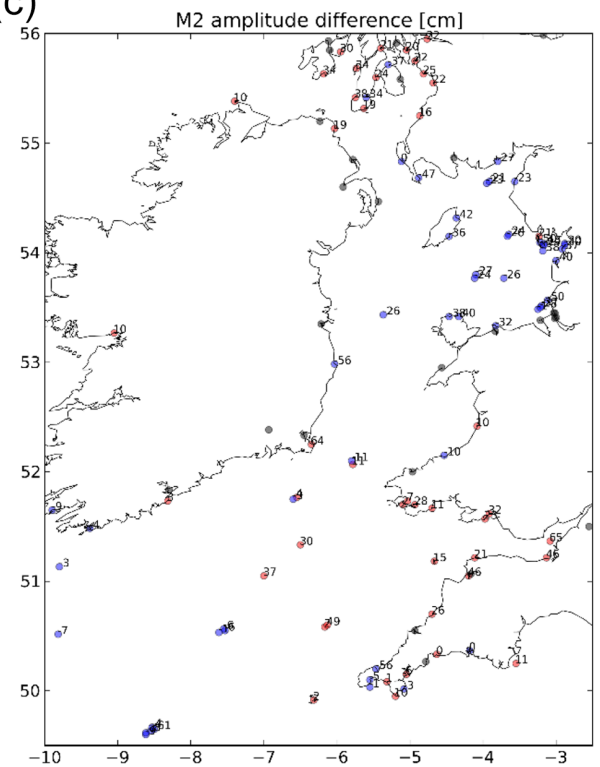

(b)

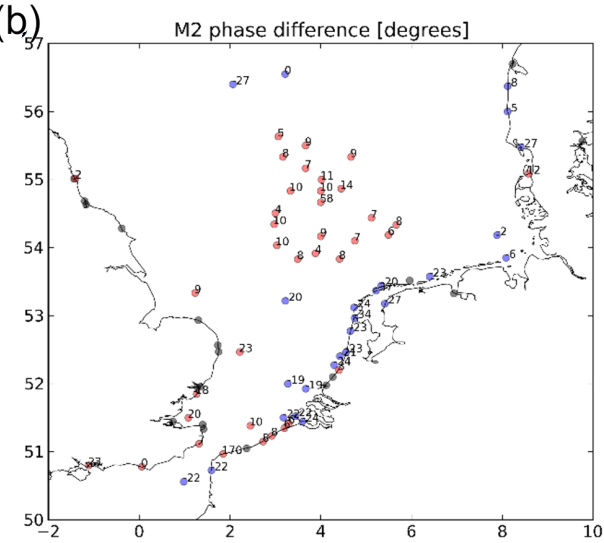

(d)

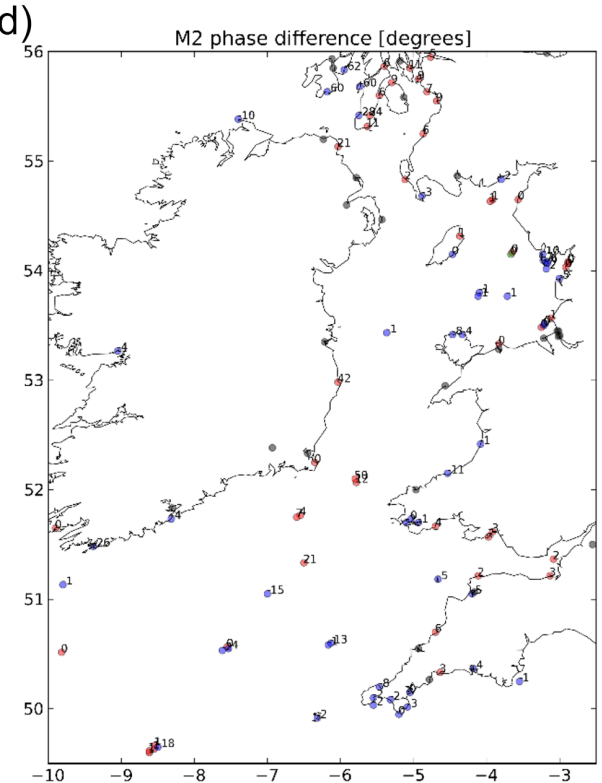

Figure 5. Spatial distribution of difference between model and observations of $\mathrm{M}_{2}$ tidal elevations. (a) Amplitude and (b) phase for the southern North Sea, and (c) amplitude and (d) phase for the Irish and Celtic seas. Blue circles: model smaller than observations; red circles: model larger than observations; grey circles: no data, or dry model grid cell at tide gauge location.

(a)

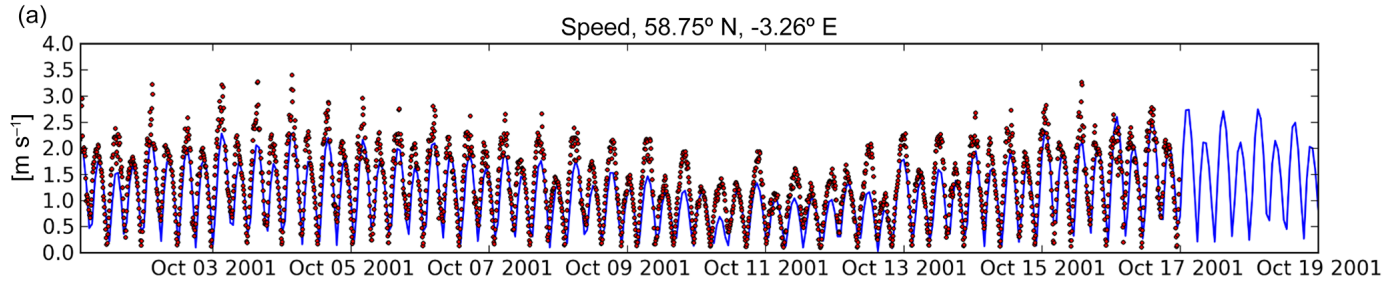

(b)

Speed, $58.75^{\circ} \mathrm{N},-3.1^{\circ} \mathrm{E}$

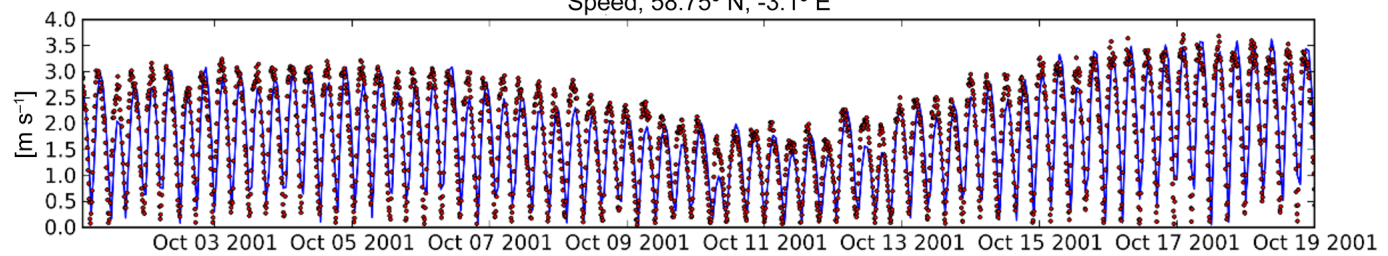

Figure 6. Comparison of modelled tidal current speed in the Pentland Firth with ADCP observations (Gardline Surveys, 2001): (a) ADCP 1 and (b) ADCP 2. Dots: observations; blue line: model results. For locations see Fig. 2. 
(a)

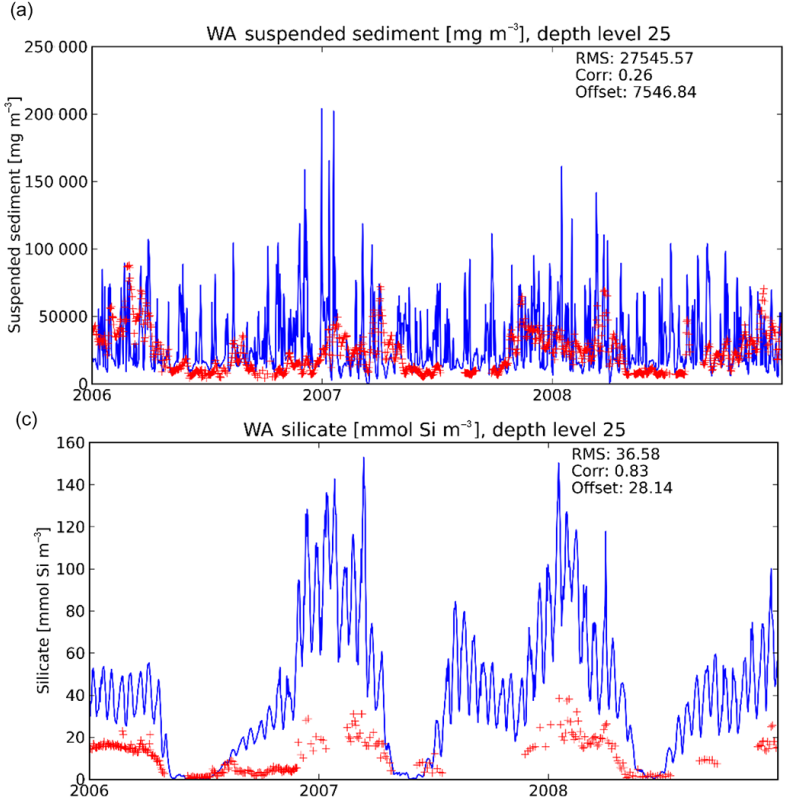

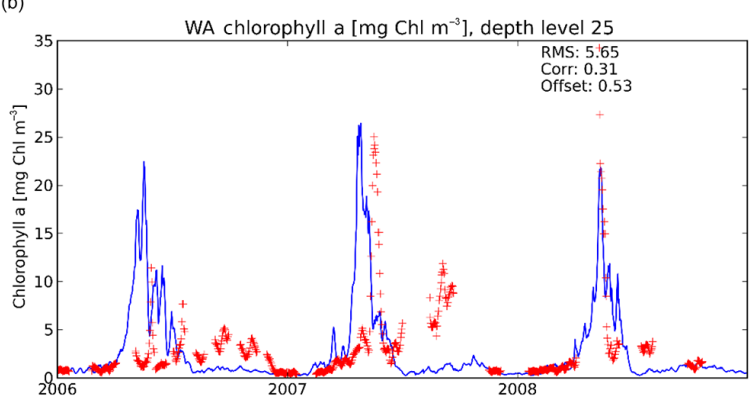

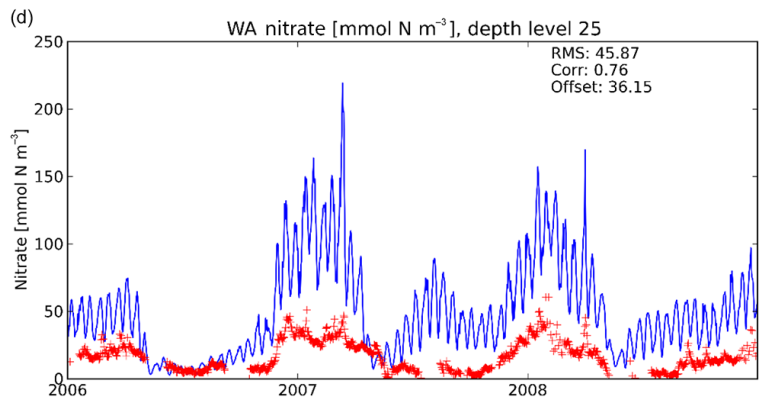

Figure 7. Comparison of model (blue line) with observations (red crosses), for the Warp Anchorage SmartBuoy. (a) SPM, (b) chlorophyll, (c) silicate, and (d) nitrate.

(a)

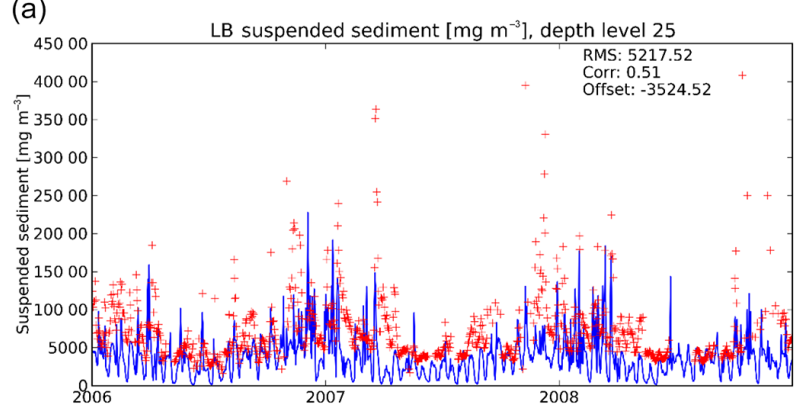

(c)

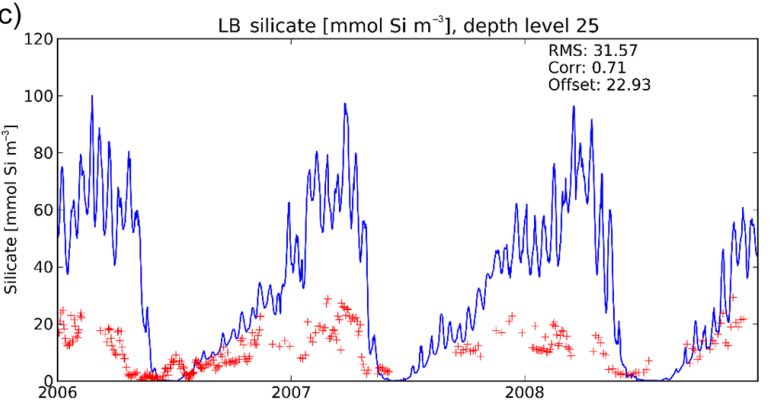

(b)

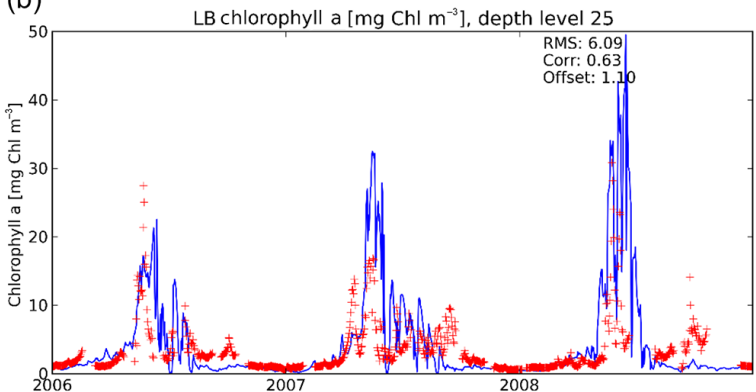

(d)

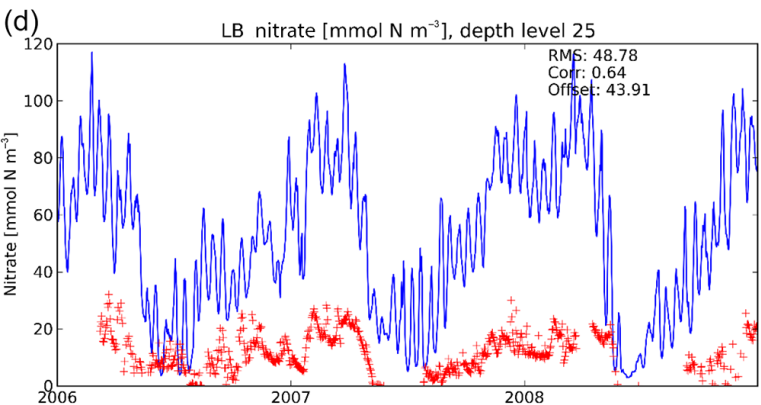

Figure 8. Comparison of model (blue line) with observations (red crosses), for the Liverpool Bay SmartBuoy. (a) SPM, (b) chlorophyll, (c) silicate, (d) nitrate.

\subsection{Effects on biogeochemistry and ecosystem}

The model detected increases in annually averaged currentinduced bed-shear stress around the Orkneys for both the $800 \mathrm{MW}$ scenario (Fig. 15c) and the $8 \mathrm{GW}$ scenario (Fig. 15e) (see Fig. 15a for the results of the reference run). Moreover, reductions in shear stress were detected all along the UK east coast, with largest reductions in the vicinity of the Wash. For the $8 \mathrm{GW}$ scenario, an increase was detected in the Strait of Dover. Furthermore, small changes were apparent in the English Channel and to the south of Ireland up to the shelf edge, most likely due to the change in the tides in the North Sea at the partially reflecting boundary that the 

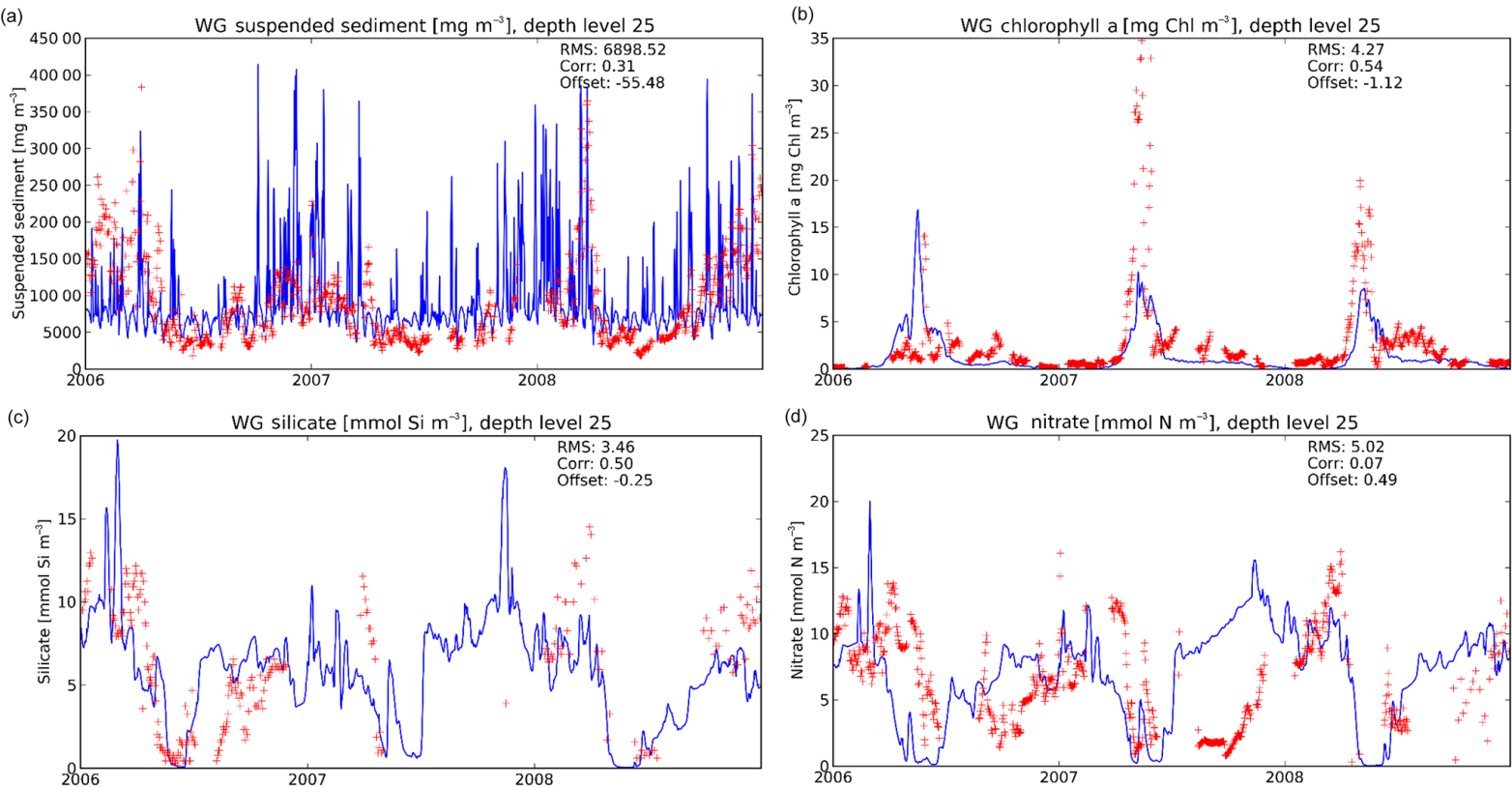

Figure 9. Comparison of model (blue line) with observations (red crosses), for the West Gabbard SmartBuoy. (a) SPM, (b) chlorophyll, (c) silicate, and (d) nitrate.
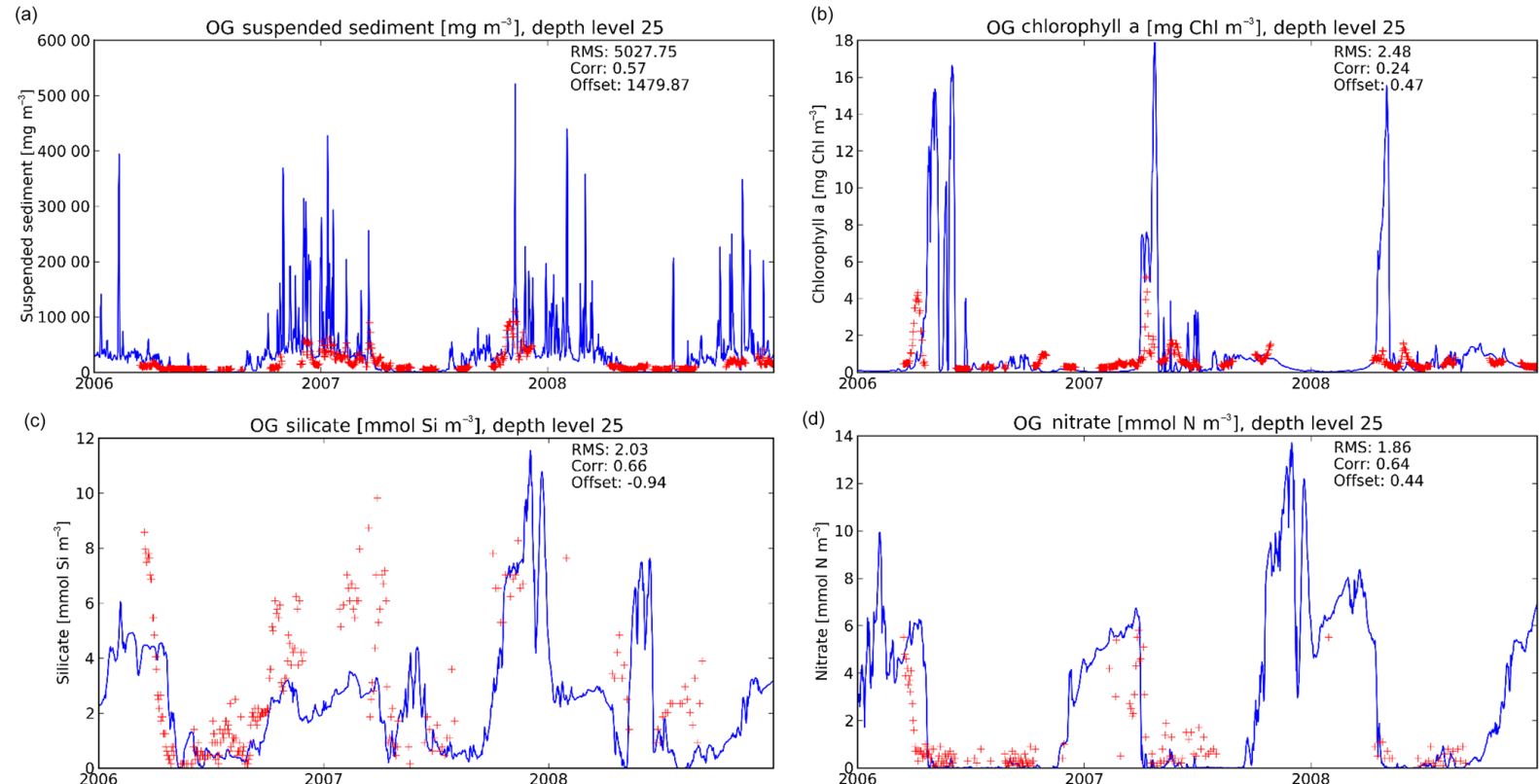

Figure 10. Comparison of model (blue line) with observations (red crosses), for the Oyster Grounds SmartBuoy. (a) SPM, (b) chlorophyll, (c) silicate, and (d) nitrate.

Strait of Dover present to this highly energetic tidal subsystem. Note that the graphical representation, with a colour change at zero, brings these features out; they would not show up if the smallest colour bin was straddling zero. At the extreme southwestern end at the shelf edge, the change was slightly more prominent, probably because the strong spatial gradients make it more sensitive to changes. For the
$800 \mathrm{MW}$ scenario, the filtering mechanism removed these small changes. For the $8 \mathrm{GW}$ scenario, depending on the location, the changes in shear stress ran up to $10 \%$ of the reference scenario. For a large area centred around the Wash, where waters are shallow and shear stresses relatively large, these changes in bed-shear stress led to a reduction in annually averaged surface SPM concentrations (Fig. 15b, d, 

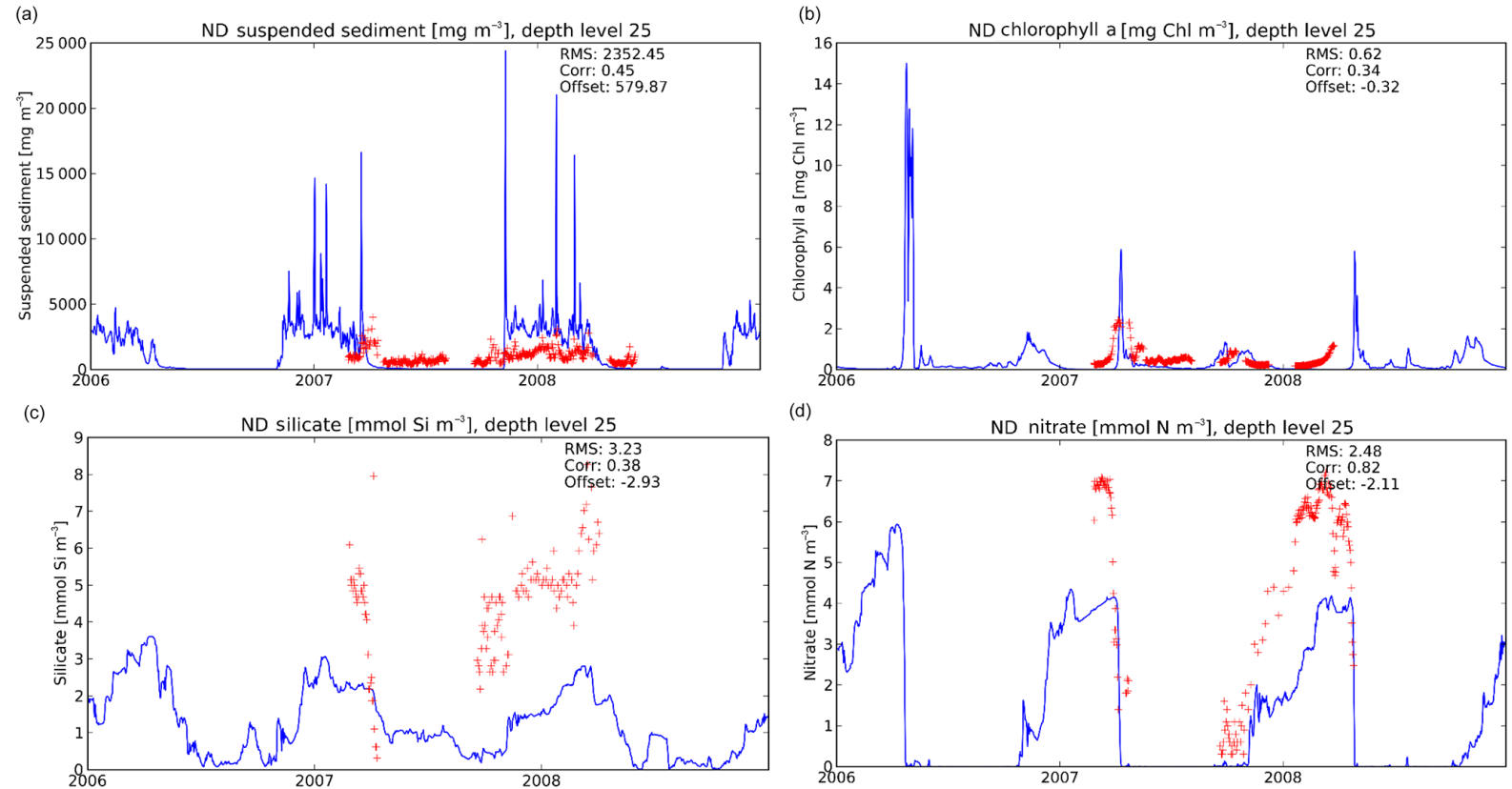

Figure 11. Comparison of model (blue line) with observations (red crosses), for the North Dogger SmartBuoy. (a) SPM, (b) chlorophyll, (c) silicate, and (d) nitrate.

f). For the $8 \mathrm{GW}$ scenario, this reduction in SPM concentration led to higher primary production in the light-limited area around the Wash as shown in Fig. 16a and e. This was caused mainly by an increase in diatoms and phaeocystis colonies (not shown). Associated with this increase was a decrease in annually averaged nutrient concentrations, shown here for nitrate (Fig. 16b, f). Similar changes were not detected for the $800 \mathrm{MW}$ scenario (Fig. 16c, d). Pelagic and benthic fauna profited from the increase in production in the $8 \mathrm{GW}$ scenario, as shown here for omnivorous mesozooplankton and suspension feeders (Fig. 17a, b, e, f). The zooplankton also showed increased biomass further north along the UK coast. This was also evident in the $800 \mathrm{MW}$ scenario (Fig. 17c), whereas suspension feeders did not show a response (Fig. 17d). The reduced bed-shear stress also induced an increase in annually averaged particulate organic carbon in the sea bed in a wide area centred around the Wash for the $8 \mathrm{GW}$ scenario (Fig. 18a, e). Again, nothing was detected for the $800 \mathrm{MW}$ scenario (Fig. 18c). For the sea-surface $\mathrm{CO}_{2}$ flux, some spatial changes were suggested for both scenarios (Fig. 18b, d, f), but no clear net change. All the results were presented for the last year of the 3-year scenario runs, 2008, to allow the changes induced by introducing the turbines in January 2006 to become effective. The results were similar, however, to those found for 2006 and 2007 (not shown here for brevity), with the exception of a net air-to-sea $\mathrm{CO}_{2}$ flux for 2006, which suggests a quick transition to a state with slightly higher carbon content. In addition to the results presented here, numerous other model variables were investi- gated, but none showed significant changes not related to the mechanisms presented here.

\section{Discussion and conclusions}

\subsection{Tides}

The good agreement of the model with observed tidal characteristics in the area around Scotland and in the North Sea, and in particular with the ADCP observations within the Pentland Firth, indicated that the model is suitable to study the large-scale effects of tidal energy extraction in the Pentland Firth. The difference in tidal asymmetry between the two ADCPs suggests that local bathymetry plays an important role in these observations. Such differences cannot be expected to be picked up by a model of the resolution used. However, increasing the resolution would make the model too costly if run with a biogeochemistry model. For a very high-resolution study of tidal turbines in part of the Pentland Firth, see Martin-Short et al. (2015).

The larger differences of modelled tides with observations in the Irish and Celtic seas are most likely due to the local bathymetry, topography, and coastline geometry, which are much more complex over extensive areas than elsewhere in the model domain and not always captured at the model resolution, combined with very high tidal ranges. These kind of differences have also been reported before for other models of the Irish and Celtic seas and have been shown to reduce with increased model resolution (Jones and Davies, 1996; Young et al., 2004; Jones and Davies, 2007). The validation 

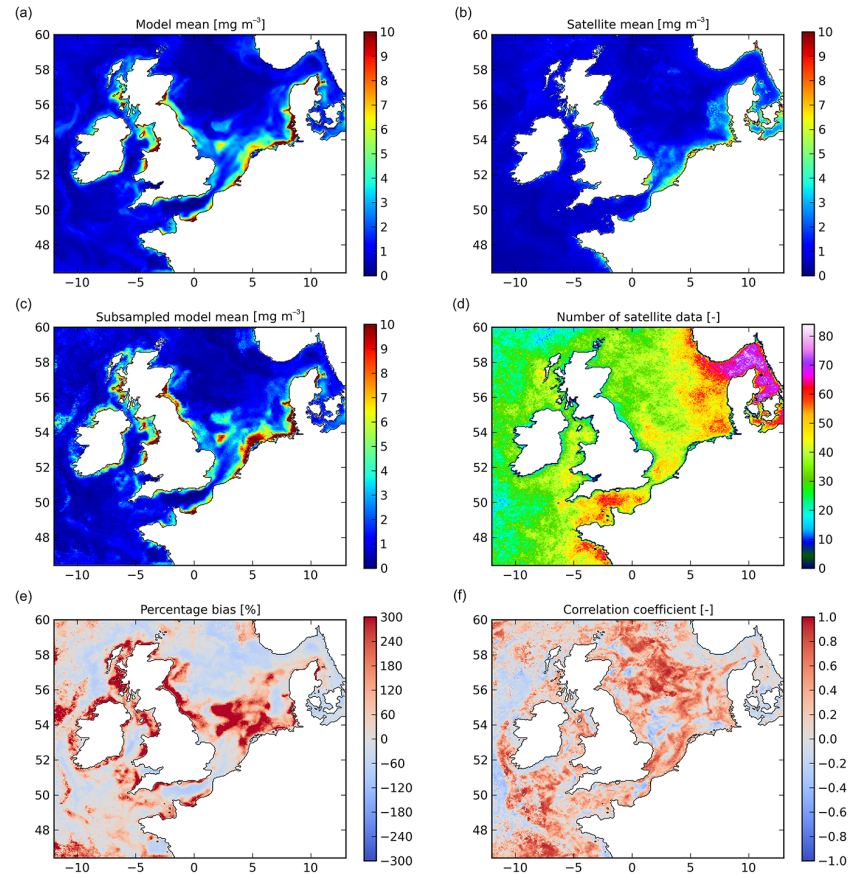

Figure 12. Comparison of modelled daily surface chlorophyll concentrations with daily chlorophyll composites from the MODIS satellite (Gohin et al., 2005; Gohin, 2011) for the growing season from 1 March to 30 September 2008. (a) Model growing-season average, (b) satellite growing-season average, (c) subsampled model growing-season average with cloudy pixels removed, (d) number of clear days in the period according to the satellite, (e) relative model bias compared to the satellite, and (f) correlation coefficient between model and satellite.
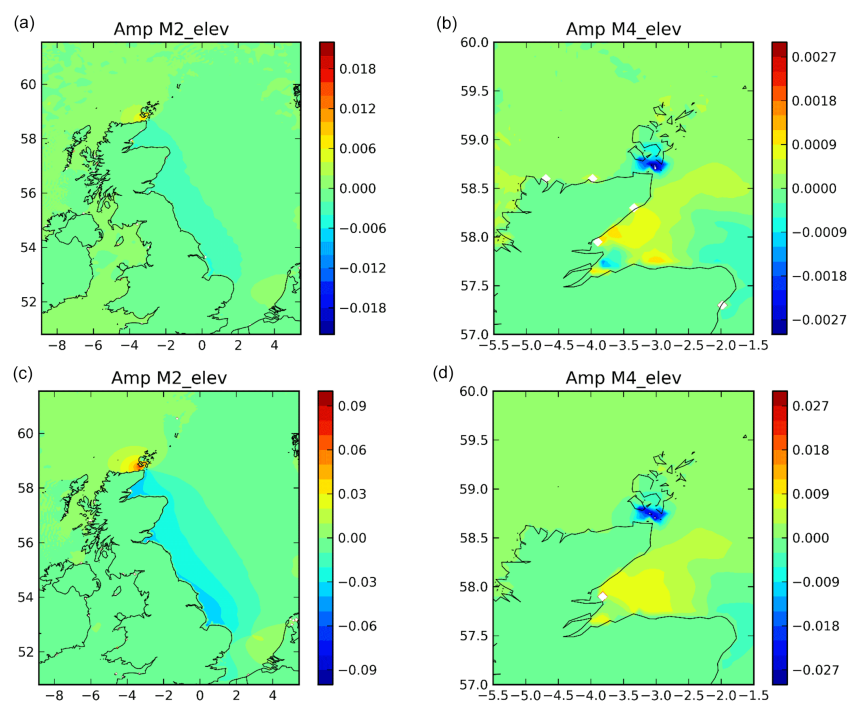

Figure 13. Difference in tidal elevations between scenario run and reference run. (a) $\mathrm{M}_{2}$ amplitude [m] and (b) M4 amplitude [m] for the $800 \mathrm{MW}$ extraction scenario. (c) $\mathrm{M}_{2}$ amplitude [m] and (d) M4 amplitude $[\mathrm{m}]$ for the $8 \mathrm{GW}$ extraction scenario.
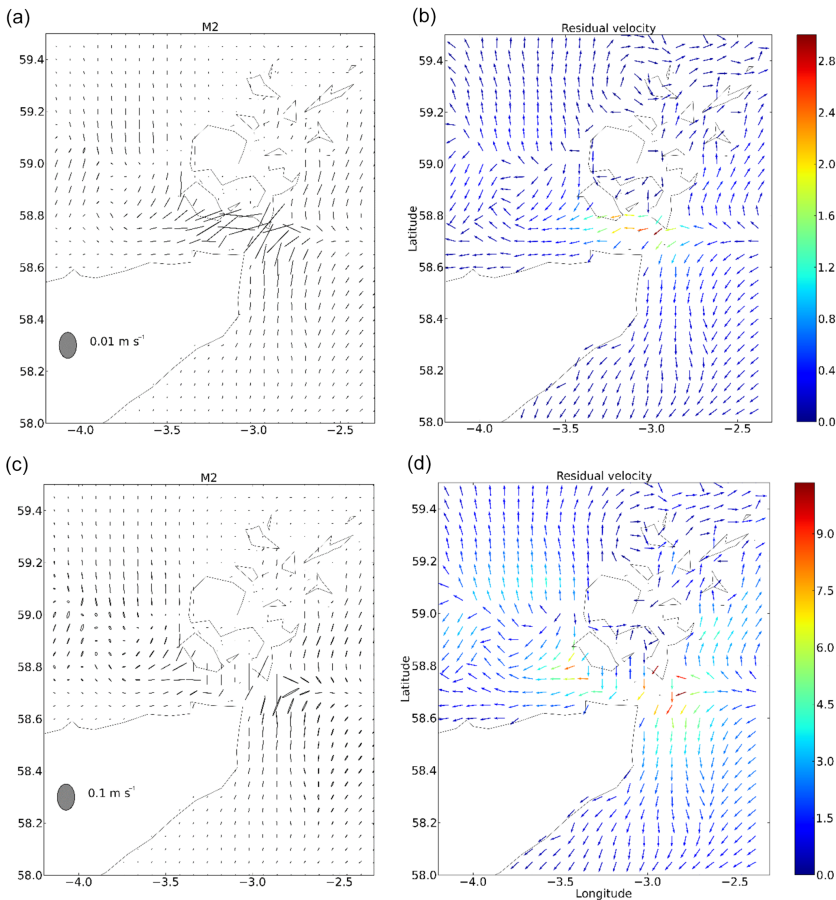

Figure 14. Difference in currents between scenario run and reference run. (a) $\mathrm{M}_{2}$ tidal current ellipses and (b) residual currents $\left[\mathrm{cm} \mathrm{s}^{-1}\right.$ ] for the $800 \mathrm{MW}$ extraction scenario. (c) $\mathrm{M}_{2}$ tidal current ellipses and (d) residual currents $\left[\mathrm{cm} \mathrm{s}^{-1}\right.$ ] for the $8 \mathrm{GW}$ extraction scenario.

results indicate that these differences are contained within the Celtic and Irish seas, and hence are unlikely to influence the changes in tides, SPM concentrations and biogeochemistry found in the North Sea in response to the tidal power extraction scenarios presented here.

The model results for the $800 \mathrm{MW}$ scenario suggested that far-field effects on tidal elevations, currents, and residual circulation would be negligible, and would most likely not be measurable. The model results for the $8 \mathrm{GW}$ scenario suggested measurable changes in the Pentland Firth and Orkneys area, and along most of east coast of the UK. This change in the tidal system is equivalent with more radical results reported by Wolf et al. (2009) for power generation with multiple barrage systems in the Irish Sea. Changes in transport pathways should be expected within the Pentland Firth and its approaches for suspended and dissolved materials due to the changes in residual flows, as well as in the Morray Firth for bed-load materials due to the increase in tidal asymmetry; similar effects of tidal stream generators on a smaller, local scale were suggested by Neil et al. (2009) and Ahmadian and Falconer (2012). It is likely that, for realistic cases, the results presented here would be modulated to some extent by the actual spatial distribution of tidal energy generation devices. The difference in the response of the $\mathrm{M}_{2}$ tidal currents within the Pentland Firth between the two scenarios 
(a)

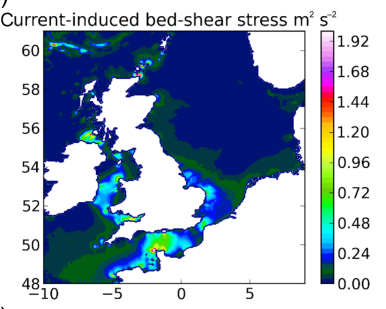

(c)

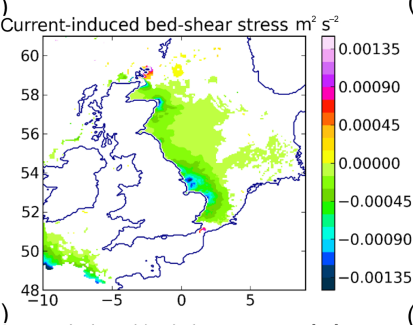

(e)

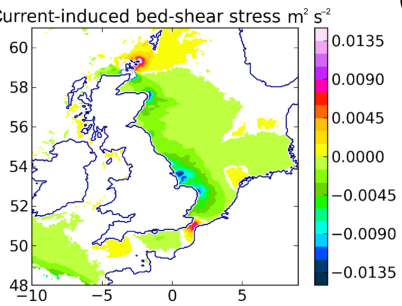

(b)

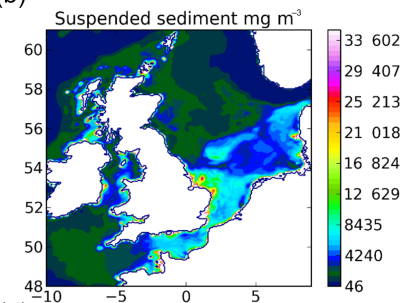

(d)

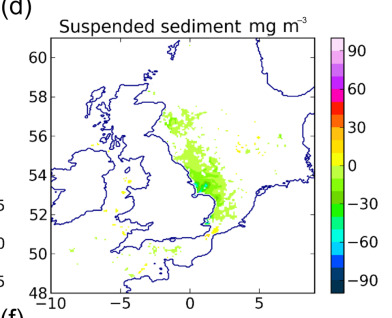

(f)

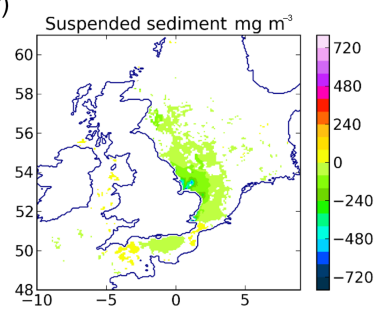

Figure 15. (a) Annually averaged current-induced bed-shear stress for 2008. (b) Annually averaged surface SPM concentration for 2008. (c, d) Changes in (a) and (b) for the 800 MW extraction scenario. (e, f) Changes in (a) and (b) for the $8 \mathrm{GW}$ extraction scenario. White areas were masked out.

suggests a change to complete friction-dominated conditions in the $8 \mathrm{GW}$ scenario, resulting in only small changes in tidal velocities within the Pentland Firth as the energy extracted is compensated for by increased tidal surface elevation differences between the two ends of the channel. This result suggests that, as far as the response of the local tidal system within the Pentland Firth is concerned, large amounts of tidal energy can potentially be harvested without reducing the effectiveness of individual turbines by a reduction in overall current speeds. This result contrasts with that found by Shapiro (2011) for a farm at open sea, where the tidal flow progressively evaded the farm area with increasing power extraction.

The changes in tidal amplitude along the east coast of the UK suggest that local, high-resolution model studies of the impact of tidal energy devices should include sufficiently large spatial scales (in this case up to a few thousands of kilometres) to prevent boundary conditions from affecting the results, by (i) using large-scale models with local grid refinement, (ii) two-way nested models, or (iii) one-way nested models with inclusion of the energy extraction at all nest levels.

(a)

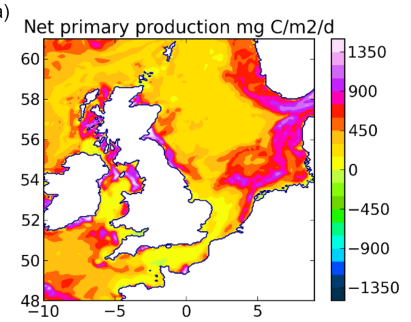

(c) Net primary production $\mathrm{mg} \mathrm{C} / \mathrm{m} 2 / \mathrm{d}$

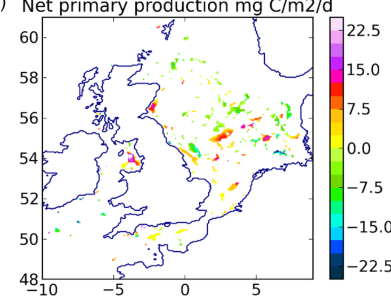

(e)

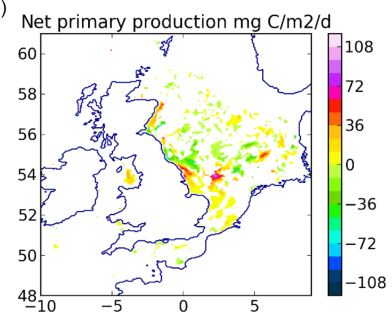

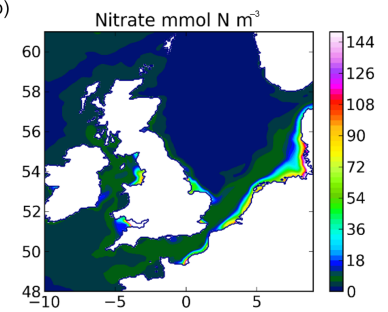

(d)

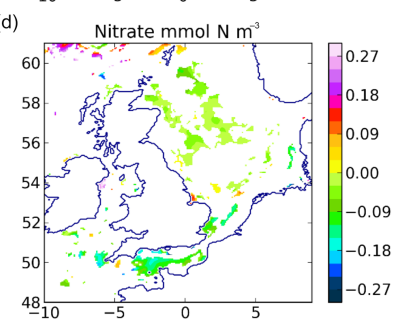

(f)

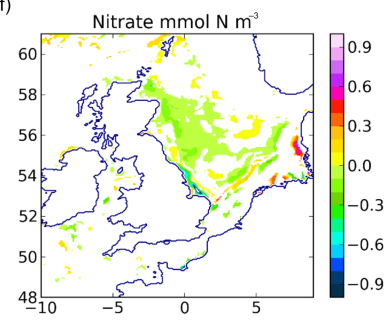

Figure 16. (a) Annually averaged net primary production for 2008 . (b) Annually averaged surface nitrate concentration for 2008. (c, d) Changes in (a) and (b) for the $800 \mathrm{MW}$ extraction scenario. (e, f) Changes in (a) and (b) for the $8 \mathrm{GW}$ extraction scenario. White areas were masked out.

\subsection{Biogeochemistry}

The model results for SPM, chlorophyll, nitrate, and silicate corresponded well to time-series observations from five stations situated in very different hydrographic conditions. The exception was winter-nutrient concentrations in the nearshore locations, which were overestimated. As the most dominant effects of the tidal energy extraction scenarios were in a very turbid area where phytoplankton growth is light-limited, this artifact is not expected to affect the main results of this study.

For the $800 \mathrm{MW}$ scenario, as was to be expected from the minor changes in tidal conditions, and apart from coherent minor changes in bed-shear stress and SPM concentrations along the central and southern parts of the UK east coast, the biogeochemical model did not demonstrate clear differences with the reference scenario.

For the $8 \mathrm{GW}$ scenario, changes in ecosystem variables of up to $10 \%$ were simulated in a substantial area in the vicinity of the Wash. The mechanism was through reduced bed-shear stress, reduced SPM concentrations, and increased light availability, leading to increased primary production, secondary production, and benthic biomass. This mechanism has also been identified in earlier studies on potential and ob- 


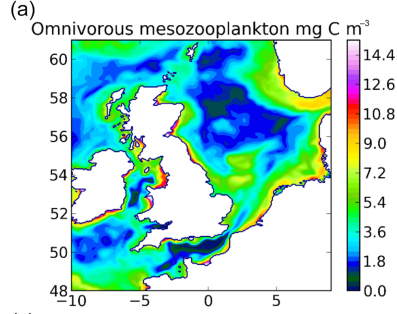

(c)

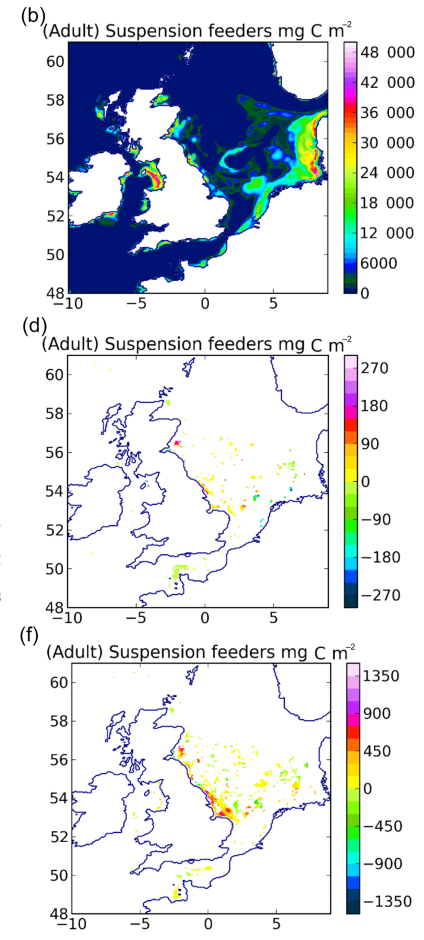

(d)

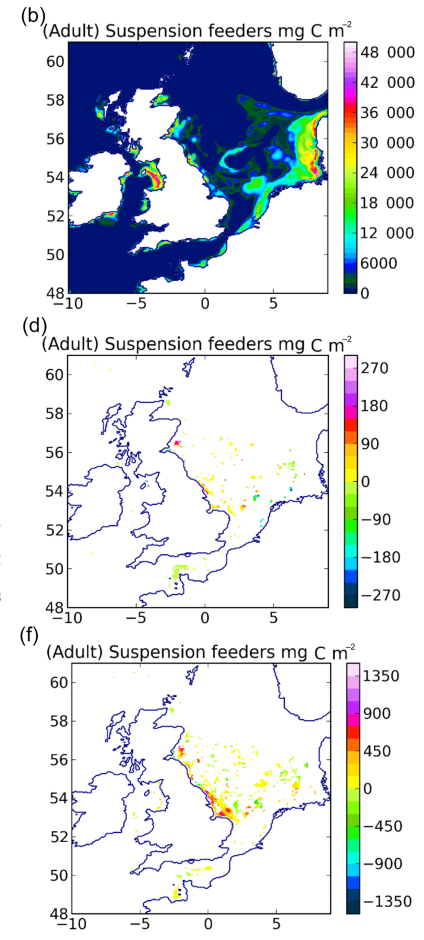

(e)
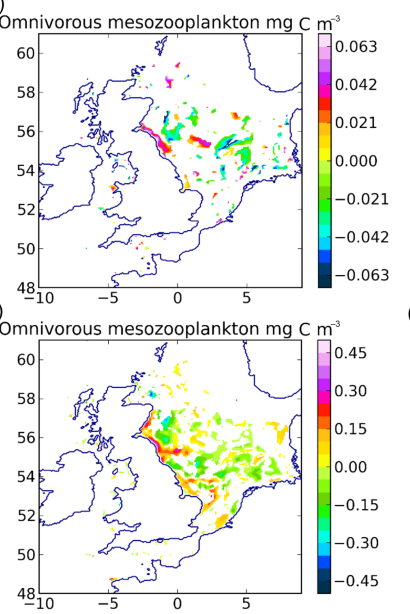

Figure 17. (a) Annually averaged omnivorous mesozooplankton carbon biomass for 2008. (b) Annually averaged suspension feeder carbon biomass for 2008. (c, d) Changes in (a) and (b) for the $800 \mathrm{MW}$ extraction scenario. (e, f) Changes in (a) and (b) for the $8 \mathrm{GW}$ extraction scenario. White areas were masked out.

served effects of tidal barrages (Radford and Ruardij, 1987; Kadiri et al., 2012; Hooper and Austen, 2013). These studies focused on the local scale, however, making direct comparison and contrasting of barrage and tidal stream methods difficult because the present study does not resolve the local scales in detail. For some ecosystem variables, changes also occurred further north along the coast. In terms of carbon cycling, we found a minor increase in particulate carbon content in the sea bed in the area associated with the increase in productivity. This increase was most likely caused primarily by a combination of increased production of detrital material, improved hydrodynamic conditions for settling of particulates, and a reduction in current-induced resuspension relative to the amount of detritus in the sediments (the absolute resuspension and settling rates increased, but to a smaller proportion than the content of detritus in the sediments). Aerobic benthic bacterial biomass also increased in the model, so the increase in particulate carbon in the sea bed was probably reduced by an increase in bacterial decomposition. It is possible that changes in bioturbation associated with the increase in benthic biomass also influenced the balance, but information on this activity was not stored. This increase in benthic particulate organic carbon content appeared to be a one-off, acquired as the system adjusted in the first year of

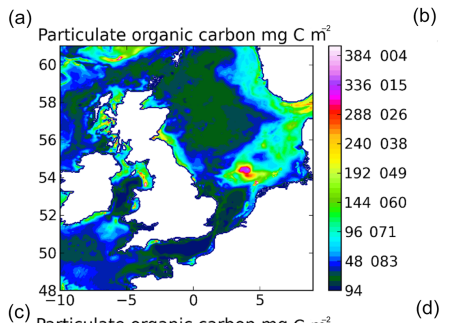

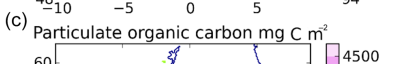

b)

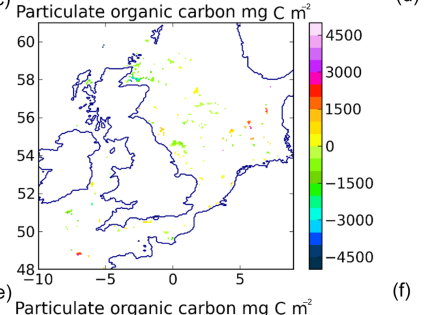

(e)
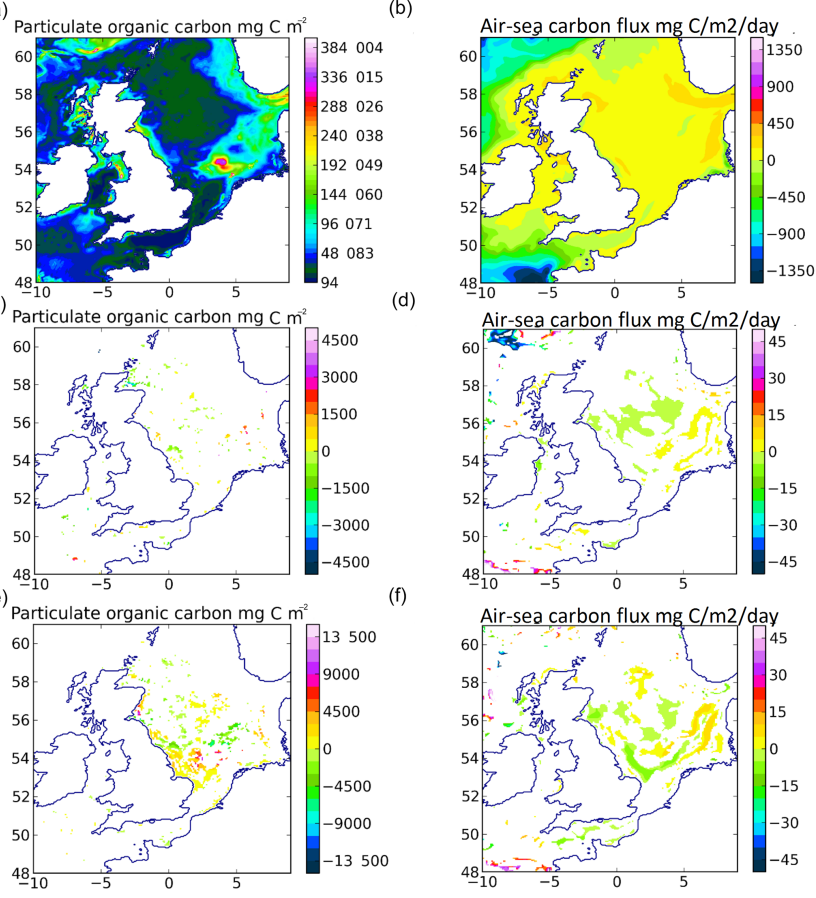

Figure 18. (a) Annually averaged benthic particulate organic carbon for 2008. (b) Annually averaged sea-surface $\mathrm{CO}_{2}$ flux for 2008 . (c, d) Changes in (a) and (b) for the $800 \mathrm{MW}$ extraction scenario. (e, f) Changes in (a) and (b) for the $8 \mathrm{GW}$ extraction scenario. White areas were masked out.

the scenario simulation, and did not change substantially in the subsequent 2 years.

\section{Concluding remarks}

The model did not detect significant changes for the currently licensed energy extraction of $800 \mathrm{MW}$, with potential exception of residual currents in the vicinity of the Pentland Firth. These need to be investigated further, at higher resolution, and in conjunction with particle tracking to assess potential effects on larval dispersal and recruitment. A broad area in the vicinity of the Wash appeared to be most sensitive to the massive-expansion $8 \mathrm{GW}$ scenario. The model results indicated an increase in productivity. Local fisheries could benefit, in particular those relating to shell fish and crustaceans. A limited, one-off increase in carbon storage in the sea bed was simulated, which could be regarded as an additional positive contribution to mitigating $\mathrm{CO}_{2}$-induced climate change. However, the authors are of the opinion that further investigations of far-field effects would be advisable if tidal energy extraction were planned beyond the currently licensed $800 \mathrm{MW}$, or if substantial additional tidal energy extraction were planned at other sites along the coast, as the effects of multiple sites are likely to interact (Wolf et al., 2009). Moreover, interactions with climate change and potential effects 
of other marine renewable energy generation schemes should be investigated.

Acknowledgements. This research was financially supported by EPSRC grant EP/J010065/1. The model development was funded by Cefas Seedcorn projects DP261 and DP315. Claire Coughlan, while at JRC (Ispra), created the open-boundary forcing for temperature, salinity, and nutrients. The SmartBuoy data were collected in projects A1228, AE004, and SLA25 funded by Defra as part of the National Eutrophication Monitoring Programme. The SmartBuoy in Liverpool Bay forms part of the Liverpool Bay Coastal Observatory (www.cobs.pol.ac.uk) coordinated by the Proudman Oceanographic Laboratory. ECMWF and BADC are thanked for making the atmospheric forcing available.

Edited by: C. Woulds

\section{References}

Ahmadian, R. and Falconer, R. A.: Assessment of array shape of tidal stream turbines on hydro-environmental impacts and power output, Renew. Energ., 44, 318-327, 2012.

Aldridge, J., van der Molen, J., and Forster, R.: Wider ecological implications of Macroalgae cultivation, The Crown Estate, Edinburgh, London, ISBN 978-1-906410-38-4, 95 pp., 2012.

Balmaseda, M. A., Mogensen, K., and Weaver, A.: Evaluation of the ECMWF Ocean Reanalysis ORAS4, Q. J. Roy. Meteor. Soc., 139, 1132-1161, doi:10.1002/qj.2063, 2013.

Baretta, J. W., Ebenhöh, W., and Ruardij, P.: The European Regional Seas Ecosystem Model, a complex marine ecosystem model, Neth. J. Sea Res., 33, 233-246, 1995.

Boehlert, G. and Gill, A.: Environmental and ecological effects of ocean renewable energy development: A current synthesis, Oceanography, 23, 68-81, 2010.

Burchard, H. and Bolding, K.: GETM - a general estuarine transport model, Scientific documentation, Tech. Rep. EUR 20253 EN, European Commission, Ispra, Italy, 2002.

Cada, G., Ahlgrimm, J., Bahleda, M., Bigford, T., Stavrakas, S., Hall, D., Moursund, R., and Sale, M.: Potential impacts of hydrokinetic and wave energy conversion technologies on aquatic environments, Fisheries, 32, 174-180, 2007.

Crown Estate: Pentland Firth and Orkney Waters Strategic Area Review Project, www.thecrownestate.co.uk/media/5446/ pfow-strategic-area-review-project-2012.pdf (last access: December 2015), 8 pp., 2013.

Defne, Z., Haas, K. A., and Fritz, H. M.: Numerical modelling of tidal currents and the effect of power extraction on estuarine hydrodynamics along the Georgia coast, USA, Renew. Energ., 36, 3461-3471, 2011.

Dillon, L. J.: Tidal energy in the Pentland Firth, Scotland: High Resolution Mapping using GIS techniques, MS Thesis, University of Aberdeen, Aberdeen, 2007.

Easton, M. C., Woolf, D. K., and Bowyer, P. A.: The dynamics of an energetic tidal channel, the Pentland Firth, Scotland, Cont. Shelf Res., 48, 50-60, 2012.

Engel, A.: The role of transparent exopolymer particles (TEP) in the increase in apparent particle stickiness $(\alpha)$ during the decline of a diatom bloom, J. Plankton Res., 22, 485-497, 2000.
European Centre for Medium-Range Weather Forecasts (ECMWF): Assimilated Data from the European Centre for MediumRange Weather Forecasts (ECMWF) operational analysis program, NCAS British Atmospheric Data Centre, http://catalogue. ceda.ac.uk/uuidf6ce34fc/c462480467660a36d9b10a71 (last access: January 2012), 2006b.

European Centre for Medium-Range Weather Forecasts (ECMWF): European Centre for Medium-Range Weather Forecasts (ECMWF) 40-year Re-Analysis (ERA-40) model data, NCAS British Atmospheric Data Centre, http://catalogue.ceda.ac.uk/ uuid/775634f7e339b5262067e28a5d7b679d (last access: July 2007), 2006a.

European Commission: Establishing a framework for community action in the field of marine environmental policy (Marine Strategy Framework Directive), Directive 2008/56/EC, Strassbourg, 2008.

Frid, C., Andonegi, E., Depestele, J., Judd, A., Rihan, D., Rogers, S. I., and Kenchington, E.: The environmental interactions of tidal and wave energy generation devices, Environ. Impact Assess., 32, 133-139, 2012.

Funke, S. W., Farrell, P. E., and Piggot, M. D.: Tidal turbine array optimisation using the adjoint approach, Renew. Energ., 63, 658673, 2014.

Gardline Surveys: Pentland Firth - Tidal Stream Observations, Report Produced for the Navigation Safety Branch of the Maritime and Coastguard Agency, Contract NBSA5B/2959, Gardline, Great Yarmouth, UK, 57 pp., 2001.

Garcia, H. E., Locarnini, R. A., Boyer, T. P., Antonov, J. I., Zweng, M. M., Baranova, O. K., and Johnson, D. R.: World Ocean Atlas 2009, Volume 4, Nutrients (phosphate, nitrate, silicate), edited by: S. Levitus, NOAA Atlas NESDIS 71, US Government Printing Office, Washington, D.C., 398 pp., 2010.

Gill, A.: Offshore renewable energy: Ecological implications of generating electricity in the coastal zone, J. Appl. Ecol., 42, 605$615,2005$.

Gjevik, B. and Straume, T.: Model simulations of the M2 and the K1 tide in the Nordic Seas and the Arctic Ocean, Tellus, 41A, 73-96, 1989.

Gohin, F.: Annual cycles of chlorophyll- $a$, non-algal suspended particulate matter, and turbidity observed from space and in-situ in coastal waters, Ocean Sci., 7, 705-732, doi:10.5194/os-7-7052011, 2011.

Gohin, F., Loyer, S., Lunven, M., Labry, C., Froidefond, J. M., Delmas, D., Huret, M., and Herbland, A.: Satellite-derived parameters for biological modelling in coastal waters: Illustration over the eastern continental shelf of the Bay of Biscay, Remote Sens. Environ., 95, 29-46, 2005.

Gowen, R. J., Tett, P., Kennington, K., Mills, D. K., Shammon, T. M., Stewart, B. M., Greenwood, N., Flanagan, C., Devlin, M., and Wither, A.: The Irish Sea: Is it eutrophic?, Estuar. Coast. Shelf S., 76, 239-254, 2008.

Greenwood, N., Parker, E. R., Fernand, L., Sivyer, D. B., Weston, K., Painting, S. J., Kröger, S., Forster, R. M., Lees, H. E., Mills, D. K., and Laane, R. W. P. M.: Detection of low bottom water oxygen concentrations in the North Sea; implications for monitoring and assessment of ecosystem health, Biogeosciences, 7, 1357-1373, doi:10.5194/bg-7-1357-2010, 2010.

Holt, J. T., James, I. D., and Jones, J. E.: An s coordinate density evolving model of the northwest European continental shelf, part 
2, Seasonal currents and tides, J. Geophys. Res., 106, 1403514053, 2001.

Hooper, T. and Austen, M.: Tidal barrages in the UK: ecological and social impacts, potential mitigation, and tools to support barrage planning, Renew. Sust. Energ. Rev., 23, 289-298, 2013.

Jones, J. E.: Charts of the O1, K1, N2, M2, and S2 tides in the Celtic Sea including M2 and S2 tidal currents, Institute of Oceanographic Sciences, NERC, Report 169, Wormley, UK, 59 pp., 1983.

Jones, J. E. and Davies, A. M.: A high-resolution, three-dimensional model of the M2, M4, M6, S2, N2, K1 and O1 tides in the eastern Irish Sea, Estuar. Coast. Shelf S., 42, 311-346, 1996.

Jones, J. E. and Davies, A. M.: On the sensitivity of computed higher tidal harmonics to mesh size in a finite element model, Cont. Shelf Res., 27, 1908-1927, 2007.

Kadiri, M., Ahmadian, R., Bockelmann-Evans, B., Rauen, W., and Falconer, R.: A review of the potential water quality impacts of tidal renewable energy systems, Renew. Sust. Energ, Rev., 16, 329-341, 2012.

Lenhart, H. J., Mills, D. K., Baretta-Bekker, H., van Leeuwen, S. M., van der Molen, J., Baretta, J. W., Blaas, M., Desmit, X., Kühn, W., Lacroix, G., Los, H. J., Ménesguen, A., Neves, R., Proctor, R., Ruardij, P., Skogen, M. D., Vanhoutte-Grunier, A., Villars, M. T., and Wakelin, S. L.: Predicting the consequences of nutrient reduction on the eutrophication status of the North Sea, J. Marine Syst., 81, 148-170, 2010.

Le Provost, C., Lyard, F., Genco, M. L., and Rabilloud, F.: A hydrodynamic ocean tide model improved by assimilation of a satellite altimeter-derived data set, J. Geophys. Res, 103, 5513-5529, 1998.

Martin-Short, R., Hill, J., Kramer, S. C., Advis, A., Allison, P. A., and Piggott, M. D.: Tidal resource extraction in the Pentland Firth, UK: Potential impacts on the flow regime and sediment transport in the Inner Sound of Stroma, Renew. Energ., 76, 596607,2015

Mills, D. K., Greenwood, N., Kröger, S., Devlin, M., Sivyer, D. B., Pearce, D., Cutchey, S., and Malcolm, S. J.: New Approaches to Improve the Detection of Eutrophication in UK Coastal Waters, Env. Res. Eng. Management, 2, 36-42, 2005.

Mogensen, K., Alonso Balmaseda, M., and Weaver, A.: The NEMOVAR ocean data assimilation system as implemented in the ECMWF ocean analysis for System4, ECMWF Thechnical Memorandum 668, Toulouse, France, 59 pp., 2012.

Neill, S. P., Litt, E. J., Couch, S. J., and Davies, A. G.: The impact of tidal stream turbines on large-scale sediment dynamics, Renew. Energ., 34, 2803-2812, 2009.

Oreskes, N., Shrader-Frechette, K., and Belitz, K.: Verification, validation, and confirmation of numerical models in the Earth sciences, Science, 263, 641-646, doi:10.1126/science.263.5147.641, 1994.

OSPAR: Quality status report 2010, Ospar Commision, London, http://qsr2010.ospar.org (last access: December 2015), ISBN 978-1-907390-38-8, 176 pp., 2010.

Painting, S. J. and Forster, R. M.: Marine Ecosystem Connections: essential indicators of healthy, productive and biologically divers seas, Biogeochemistry, 113, 1-7, doi:10.1007/s10533-013-9838$0,2013$.

Paramor, O. A. L., Allen, K. A., Aanesen, M., Armstrong, C., Hegland, T., Le Quesne, W., Piet, G. J., Raakær, J., Rogers, S., van
Hal, R., van Hoof, L. J. W., van Overzee, H. M. J., and Frid, C. L. J.: MEFEPO North Sea Atlas, University of Liverpool, Liverpool, ISBN 090637060 4, 2009.

Peperzak, L., Colijn, F., Gieskes, W. W. C., and Peeters, J. C. H.: Development of the diatom-Phaeocystis spring bloom in the Dutch coastal zone of the North Sea: the silicon depletion versus the daily irradiance threshold hypothesis, J. Plankton Res., 20, 517-537, 1998.

Pingree, R. D., Holligan, P. M., and Mardell, G. T.: The effects of vertical stability on phytoplankton distributions in the summer on the northwest European Shelf, Deep-Sea Res., 25, 1011-1028, 1978.

Radford, P. J. and Ruardij, P.: The validation of ecosystem models of turbid estuaries, Cont. Shelf Res., 7, 1483-1487, 1987.

Rennau, H., Schimmels, S., and Burchard, H.: On the effect of structure-induced resistance and mixing on inflows into the Baltic Sea: a numerical model study, Coast. Eng., 60, 53-68, 2012.

Ruardij, P. and van Raaphorst, W.: Benthic nutrient regeneration in the ERSEM-BFM ecosystem model of the North Sea, Neth. J. Sea Res., 33, 453-483, 1995.

Ruardij, P., van Haren, H., and Ridderinkhof, H.: The impact of thermal stratification on phytoplankton and nutrient dynamics in shelf seas: a model study, J. Sea Res., 38, 311-331, 1997.

Ruardij, P., Veldhuis, M. J. W., and Brussaard, C. P. D.: Modeling the bloom dynamics of the polymorphic phytoplankter Phaeocystis globosa: impact of grazers and viruses, Harmf. Algae., 4, 941-963, 2005.

Shapiro, G. I.: Effect of tidal stream power generation on the region-wide circulation in a shallow sea, Ocean Sci., 7, 165-174, doi:10.5194/os-7-165-2011, 2011.

Shields, M. A., Dillon, L. J., Wolff, D. K., and Ford, A. T.: Strategic priorities for assessing ecological impacts of marine renewable energy devices in the Pentland Firth (Scotland, UK), Mar. Policy, 33, 635-642, 2009.

Smithson, M. J.: Pelagic tidal constants - 3. IAPSO Publication Scientifique No. 35, Published by the International Association for the Physical Sciences of the Ocean (IAPSO) of the International Union of Geodesy and Geophysics, 191 pp., 1992.

van der Molen, J.:, The influence of tides, wind and waves on the sand transport in the southern North Sea, Cont. Shelf Res., 22, 2739-2762, 2002.

van der Molen, J., Bolding, K., Greenwood, N., and Mills, D. K.: A 1 -D vertical multiple grain size model of suspended particulate matter in combined currents and waves in shelf seas, J. Geophys. Res., 114, F01030, doi:10.1029/2008JF001150, 2009.

van der Molen, J., Aldridge, J. N., Coughlan, C., Parker, E. R., Stephens, D., and Ruardij, P.: Modelling marine ecosystem response to climate change and trawling in the North Sea, Biogeochemistry, 113, 213-236, doi:10.1007/s10533-012-9763-7, 2013.

van der Molen, J., Smith, H. C. M., Lepper, P., Limpenny, S., and Rees, J.: Predicting the large-scale consequences of offshore wind array development on a North Sea ecosystem, Cont. Shelf Res., 85, 60-72, doi:10.1016/j.csr.2014.05.018, 2014.

van der Molen, J., Ruardij, P., and Greenwood, N.: A 3D SPM model for biogeochemical modelling, with application to the northwest European continental shelf, J. Sea Res., in preparation, 2016. 
van Leeuwen, S. M., Tett, P., Mills, D. K., and van der Molen, J.: Stratified and nonstratified areas in the North Sea: long-term variability and biological and policy implications, J. Geophys. Res.Oceans 120, 4670-4686, DOI: 10.1002/2014JC010485, 2015.

Verspecht, F., Rippeth, T. P., Howarth, M. J., Souza, A. J., Simpson, J. H., and Burchard, H.: Processes impacting on stratification in a region of freshwater influence: application to Liverpool Bay, J. Geophys. Res.-Oceans, 114, C11022, doi:10.1029/2009JC005475, 2009.

Vichi, M., Oddo, P., Zavatarelli, M., Coluccelli, A., Coppini, G., Celio, M., Fonda Umani, S., and Pinardi, N.: Calibration and validation of a one-dimensional complex marine biogeochemical flux model in different areas of the northern Adriatic shelf, Ann. Geophys., 21, 413-436, doi:10.5194/angeo-21-413-2003, 2003.

Vichi, M., Ruardij, P., and Baretta, J. W.: Link or sink: a modelling interpretation of the open Baltic biogeochemistry, Biogeosciences, 1, 79-100, doi:10.5194/bg-1-79-2004, 2004.
Vichi, M., Pinardi, N., and Masina, S.: A generalized model of pelagic biogeochemistry for the global ocean ecosystem. Part I: Theory, J. Marine Syst., 64, 89-109, 2007.

Wolf, J., Walkington, I. A., Holt, J., and Burrows, R.: Environmental impacts of tidal power schemes, P. I. Civil Eng.-Mar. Eng., 162, 165-177, 2009.

Young, E. F., Aldridge, J. N., and Brown, J.: Development and validation of a three-dimensional curvilinear model for the study of fluxes through the North Channel of the Irish Sea, Cont. Shelf Res., 20, 997-1035, 2000.

Young, E. F., Brown, J., Aldridge, J. N., Horsburgh, K. J., and Fernand, L.: Development and application of a three-dimensional baroclinic model to the study of the seasonal circulation in the Celtic Sea, Cont. Shelf Res., 24, 13-36, 2004. 